Bulletin of the Natural History Museum, 2020, 13: 7-47.

Received 17 Mar 2020; Accepted 1 Maj 2020.

doi:10.5937/bnhmb2013007M

UDC: 069:5(497.11)

Review paper

\title{
NATURAL HISTORY MUSEUM: A JOURNEY THROUGH TIME AND SPACE
}

\author{
ALEKSANDRA MARAN STEVANOVIĆ \\ Natural History Museum, Njegoševa 51, 11000 Belgrade, Serbia \\ e-mail: amaran@nhmbeo.rs
}

The occasion of a great jubilee - 125 years since the founding of the Natural History Museum in Belgrade - merits highlighting certain historical circumstances, important events and personalities, as well as significant research and activities from the first 80 years of its existence. The fact that this paper will not be covering the modern period of the Museum is a consequence of the author's desire to have that time period reviewed and interpreted by other researchers - those who are still active witnesses. Extensive archive materials and the photo library of the Museum were used in the process of preparation, together with the reports on the work of the Museum, documents from the personal legacy of the first director Petar Pavlović, and memoirs of antecedent museologists Petar Stevanović and Sergei Matveyev.

Key words: Natural History Museum in Belgrade, historical context, important events, personalities, research and activities

\section{INTRODUCTION}

Museums are public cultural institutions in the service of society and its development that collect, research, preserve, interpret and exhibit material testimonies about peoples and their surroundings. Operation of a museum includes a wide range of activities: systematic collection; scientific, professional and technical processing; protection and storage; exhibition of movable cultural property; and educational work. If museums are to be able to meet their basic tasks, in addition to an appropriate building, exhibition space and depot, thay must also have appropriate professional staff and tec- 
hnical resources and their activities must be recognised and acknowledged by both the competent state institutions and the general public.

Most museums in Serbia are housed in buildings that were not purposely built to host such institutions. The Natural History Museum in Belgrade is no different in this respect. However, what distinguishes it from all the other museums are the facts that no less than 125 years after its establishment, Museum still operates in a building that is considered temporary, has neither adequate space to store its collections nor a permanent exhibition, and is consequently not able to show the interested public the great diversity and richness of objects it possesses.

The Natural History Museum in Belgrade is one of the oldest national institutions. It specialises in the protection and exhibition of movable natural objects while combining cultural, scientific and educational functions in its activities. Throughout history, it kept changing its name and territorial affiliation, but its mission has always been the same: collection, scientific and professional study, protection and popularisation of national natural heritage and raising awareness of the general public of its importance and the necessity to preserve it for future generations.

\section{A MUSEUM IS BORN}

Although different in Eastern and Western Europe due to a combination of political and social circumstances, the process of establishment of national museums and their influence on the formation of nations and nation-states confirms the fact that their development and operation was always accompanied by various political, cultural and social changes. The documents which were collected, studied and preserved in them simultaneously testify about the historical context of the development of nations and nation-states (Macdonald 2003). The British Museum was founded in 1753, the Louvre in France in 1793, the Rijksmuseum in the Netherlands in 1800, while the Prado National Museum (Royal Museum of Paintings and Sculptures) in Spain was opened to the public in 1819. With some delays, the similar process was taking place in Serbia.

The $19^{\text {th }}$ century in Serbia was marked by uprisings and struggles to gain independence from the Ottoman Empire, by political and dynastic conflicts and coups, but also by the building of a modern state, accelerated economic development, expansion of urban areas and strengthening of the bourgeoisie. The cultural life of Serbia changed in the second half of the $19^{\text {th }}$ century; the first scientific societies and the first state educational and cultural institutions were founded and their task was to research, collect and present national heritage to the people. 
Although 19 December 1895 is considered the formal date of the founding of the Natural History Museum, documents from the Museum archives (ANHM) show some other time determinants as well. They will be presented chronologically in this review. The first proposal was submitted on 6 December 1893 - the date of the session of the board of the Professors' Association at which its members initiated the founding of the Museum. Instead of it being spent on a wreath for the deceased professor of the Great School, Lazar Dokić, money was donated in the form of initial capital for the construction of the home of the first natural history museum in Serbia. The Fund for the Construction the Museum was also formed at that time, gathering numerous contributors among scientists and public figures. Its members were: Jovan Žujović, president of the Fund's board (Figure 1);

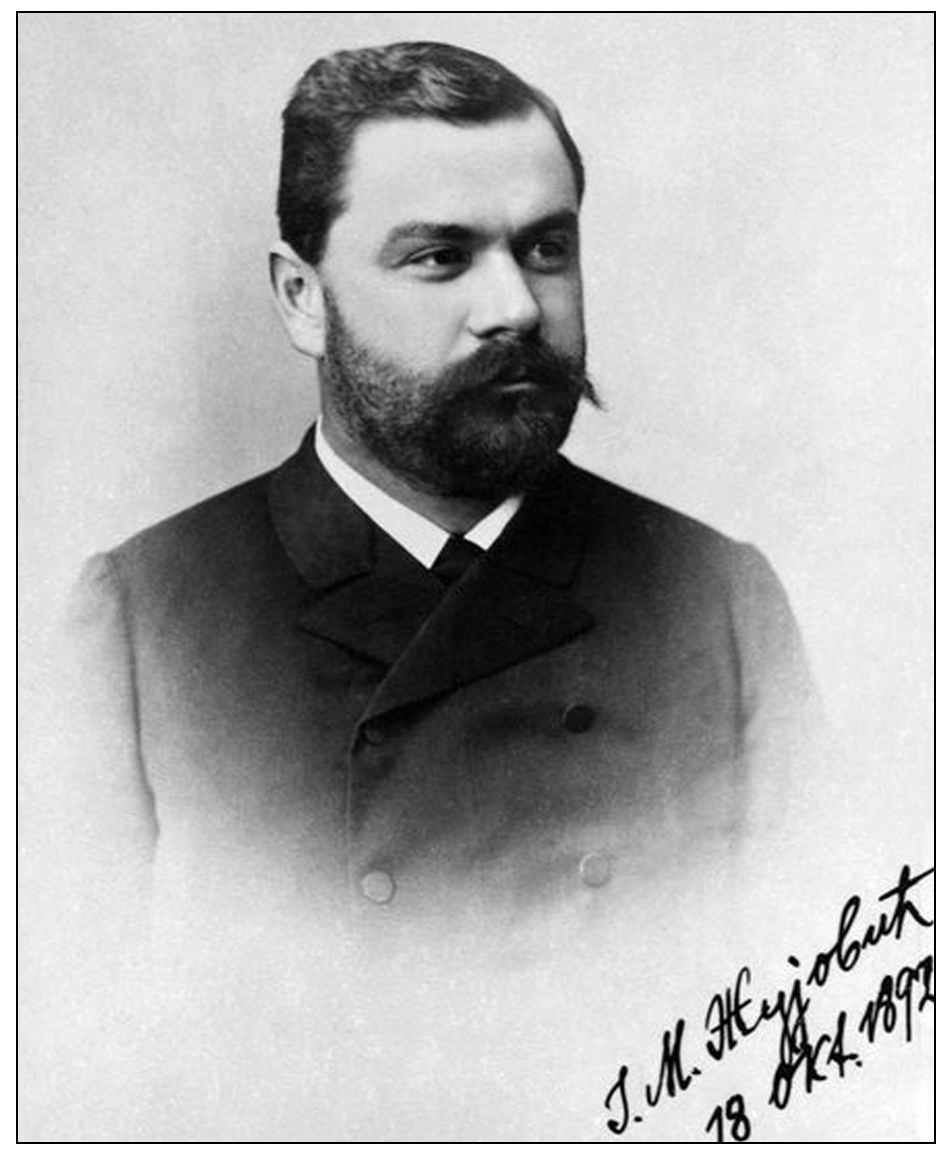

Fig. 1. - Jovan Žujović (1856-1936), professor at the Great School, president of the Serbian Royal Academy, founder and first president of the Serbian Geological Society, president of the Board of the Fund for the Construction of the Museum and the creator of the Call for the Construction of the Museum of the Serbian Land (photo: Serbian Academy of Sciences and Arts). 
Živojin Jurišić, treasurer; Petar Pavlović, administrator; Živan Živanović, Stevan Jakšić, Đorđe Jovanović, Radmilo Lazarević, Jovan Milojković, Ljubomir Miljković, Dobroslav Ružić and Sima Trojanović.

On 17 December 1895, Jovan Žujović asked the Minister of Education and Church Affairs Ljubomir Kovačević to support the establishment of the Museum, pointing out that its tasks and goals were "... to represent the entire nature of the Serbian Land, encourage, help and manage individual and systematic research conducted on Serbian lands, help teach natural sciences in all Serbian schools by compiling suitable collections of natural objects for them, and popularise this area of science in the Serbian world...".

Minister of Education and Church Affairs made the decision on the establishment on 19 December 1895 and sent a letter to the President of the Serbian Royal Academy, asking him "... to take the hereby established Museum under his supreme supervision, in the interest of science and more complete knowledge of Serbian lands, in terms of the nature these lands are endowed with" (ANHM 1895). Based on this document, the date of the Museum's founding is considered to be December 19. However, if we apply the calculation of time according to the reformed Julian calendar, the date would not be 19 December 1895, but rather 1 January 1896 (author's note).

Members of the Academy accepted their patron role in the construction of the Museum and, until 1940, the Museum published its annual reports on the work in the Yearbook of the Serbian Royal Academy (Godišnjak Srpske kraljevske akademije, Figure 2). These reports contain extremely valuable

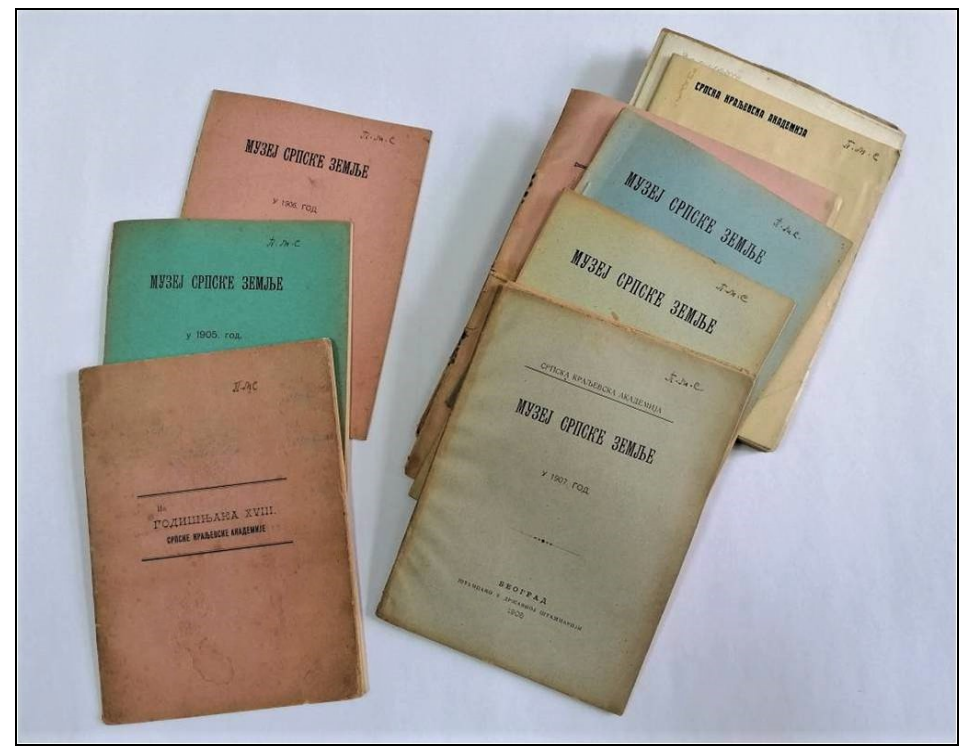

Fig. 2. - Reports on the work of the Museum of the Serbian Land, Yearbook of the Serbian Royal Academy (archive of P. Stevanović). 
data on the history of natural sciences in Serbia and the collection of material for geological, paleontological, zoological and botanical collections which served as a starting point for numerous future scientific research, works and publications.

On 1 January 1896, Serbian daily newspapers published a "Call for the Museum of the Serbian Land" (Poklič za Muzej Srpske Zemlje, Figure 3), a

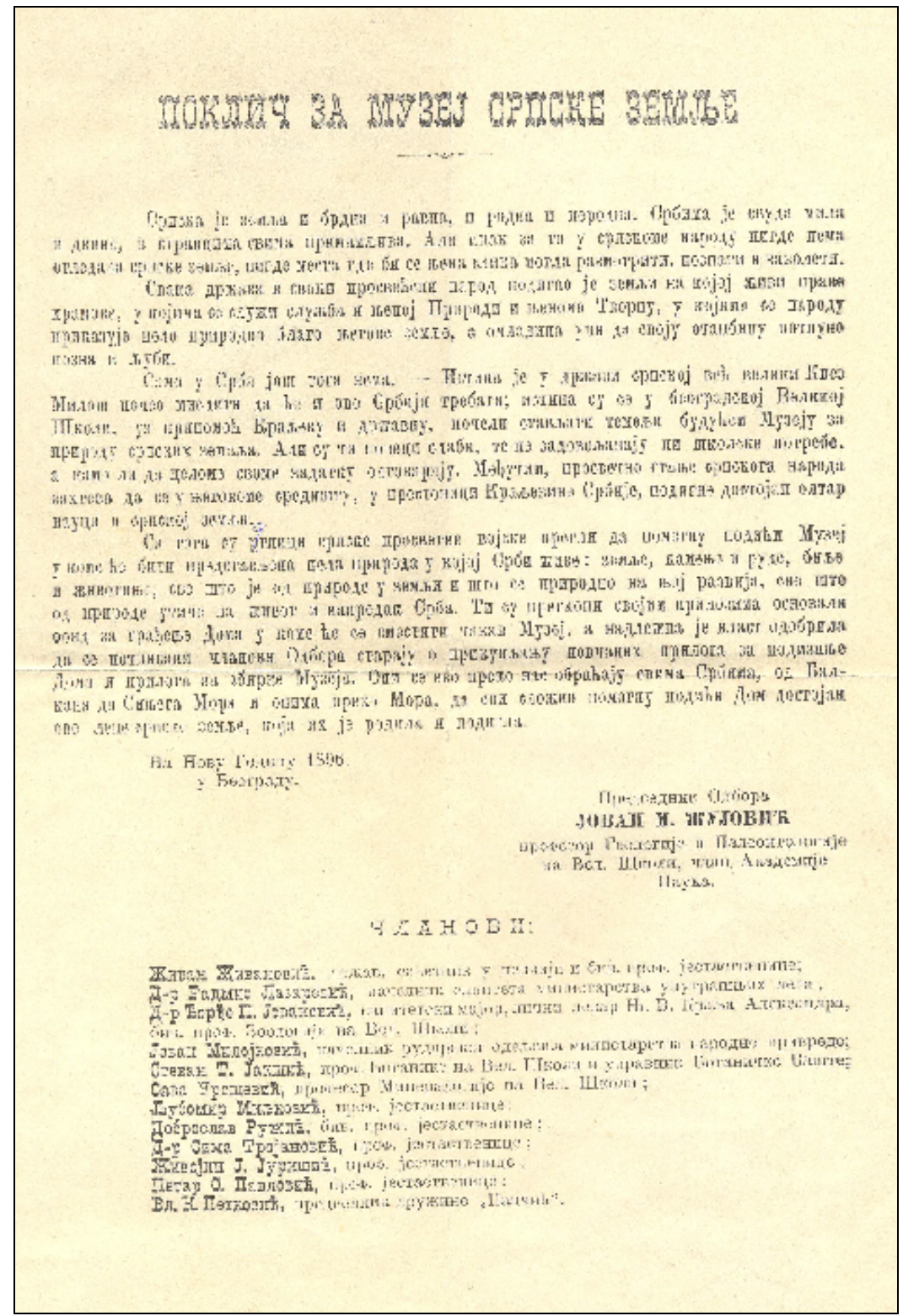

Fig. 3. - Call for the Museum of the Serbian Land. 
proclamation inviting on citizens to help establish the museum. It was pointed out in the Call that 'all the states and all the enlightened people have built real temples to the lands in which they live, in service of the Nature and its Creator, where people can see all the natural treasures of their countries so that youth can learn to fully understand and love their homeland'... and "only Serbia has no such thing yet".

The decision to build the Natural History Museum of the Serbian Land was made at the annual assembly of the Serbian Royal Academy (SRA) held on 19 January 1896. On 4 February of the same year, the National Assembly of the Kingdom of Serbia unanimously adopted the proposal of academician Milutin Garašanin, the president of National Assembly, to unite the funds - due to financial difficulties - and construct a common building which would host the Royal Academy, the National Library and the Museum, on a plot of land near the Delijska fountain which was given to the Academy by King Milan Obrenović. The plan of the Fund's board concerning the construction of the Natural History Museum and the Academy was to "erecton the plot given to the Academy a building with three fronts, so that the Academy will face the main street, the wing intended for the National Library will face the house of Nikola Spasić, and the Natural History Museum of the Serbian Land will overlook the fountain" (Inđić 2009). The plan to house three institutions under one roof was soon changed due to the realistic fear that the potential building would not be able to satisfy its triple function (Pavlović 1907: 22).

Monetary contributions for the construction of the Museum building were collected from individuals and institutions during the period 18971899 (ANHM 5/1897-1899). On 23 October 1898, the competent authorities decided to renovate the family house of Stefan Stevča Mihailović (Figure 4), bequeathed as an endowment, and move the Ethnographic Department of the National Museum and the Museum of the Serbian Land into it until the time when a new special building could be constructed (ANHM 1/1898; Anonymous 1898). Although the acquisition of this important space provided an opportunity for natural history collections to receive at least a temporary "roof over their heads", it soon turned out that the house, which was in fact intended for living, was unable to meet even the most basic museological standards.

Stefan Stevča Mihailović (1806-1888, Figure 5) was one of the most influential Serbian politicians of the $19^{\text {th }}$ century and a great philanthropist. During the reign of Prince Miloš Obrenović, he was the Vice Speaker of the St. Andrew's Assembly and Chairman of the Council of Ministers of the Principality of Serbia for two terms. After the assassination of Prince Mihailo in 1868, he was appointed one of the tutors to the minor Prince and future King Milan Obrenović (Cvetković 2011). Stevča' endowment was 
built in 1860, based on the design of architect Andrija Vuković. It was located at the intersection of Birčaninova and Miloša Velikog streets and was one of the most representative private residential buildings on a road that was, at the time, leading to Topčider. ${ }^{1}$

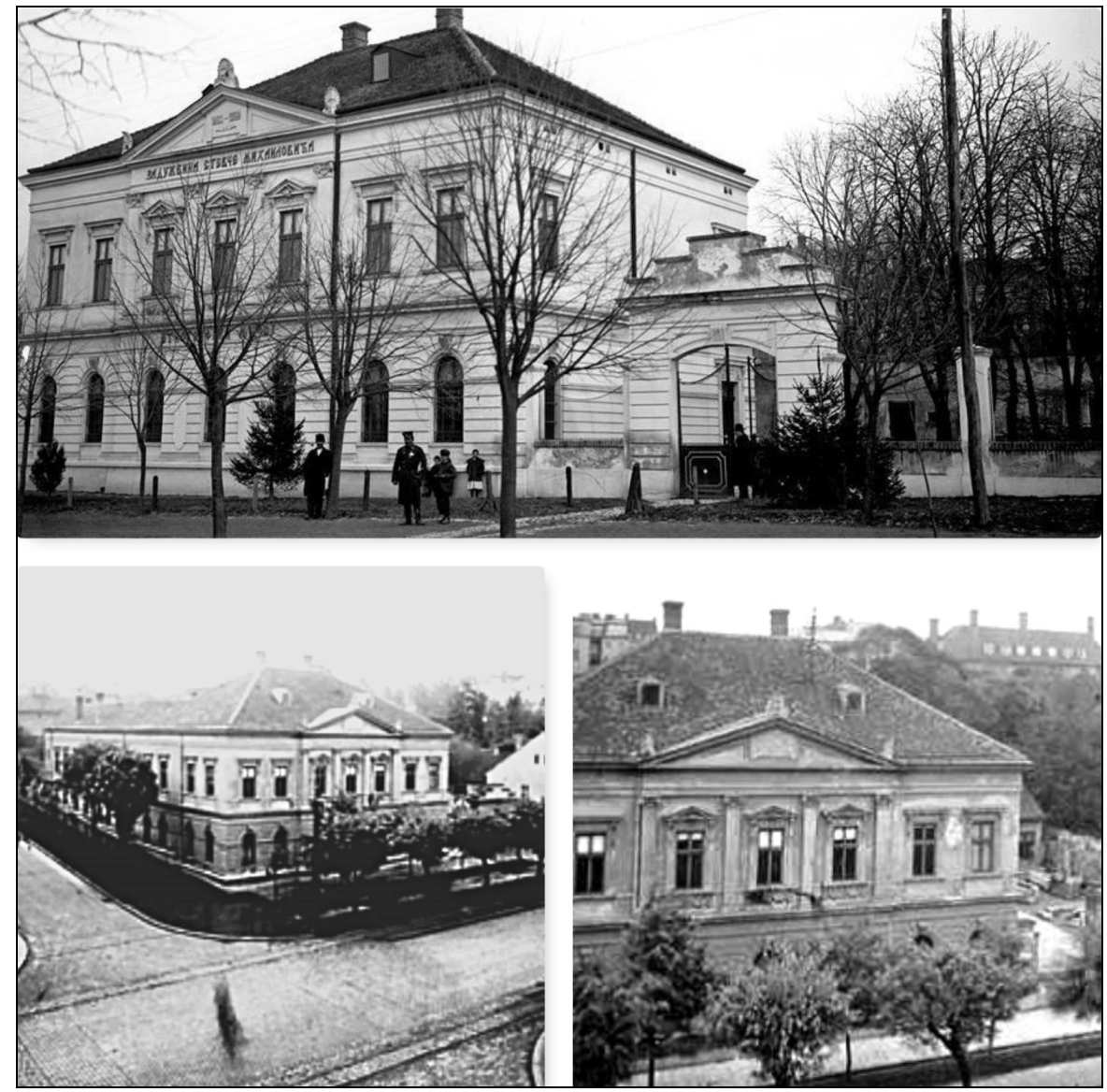

Fig. 4. - Endowment of Stevča Mihailović (archive of V. Andjelković 2009; Ethnographic Museum in Belgrade).

Preparation of the ground floor of the Stevča endowment and gathering of museum furniture necessary for the display of the initial natural history collections began in February 1901. On 4 April 1901, the Minister of Education and Church Affairs, Pavle Marinković, appointed Petar Pavlović, a professor at the Second Belgrade Gymnasium, as the first temporary

1 The endowed building was demolished in 1938. A new building was planned to be constructed on the same plot of land in September 1939, and a 20 million dinar loan was taken from the Hipotecary Bank for the purpose of building and arranging the interior of the future Museum (Weekly "Vreme" 1939). 
director of the Museum (Figure 6). It was only on 5 May 1925 that Petar Pavlović was appointed permanent director by the decree of King Alexander I Karadjordjević. Although he left behind many important and valuable scientific and expert works, Pavlović's true life's work was creating the Museum and ensuring its duration in the initial, turbulent and dramatic decades of the $20^{\text {th }}$ century.

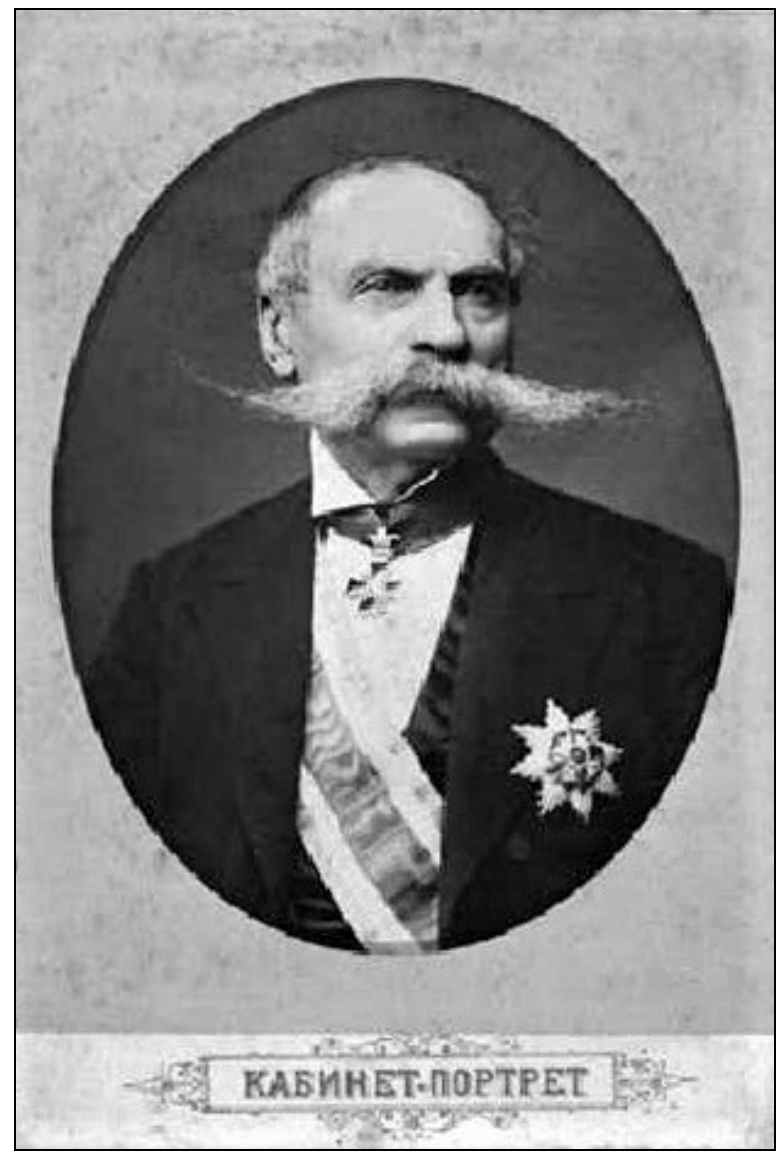

Fig. 5. - Stefan Stevča Mihailović (archive of Historical Museum of Serbia, Cvetković 2011).

The initial fund of the Museum was created between the years 1901 and 1903. With the approval of the Minister of Education and Church Affairs of 19 April 1901, a great number of natural science objects was taken from the Cabinet of Natural Sciences (Jestastvenički kabinet), the Geological Institute, the Chemical Laboratory of the Great School and the Mining Department of the Ministry of National Economy. The fund consisted of 21 collections of paleontological, petrological, mineralogical, zoological and botanical specimens of great scientific, cultural and historical significance. 
Valuable items were also gifted by numerous donors and schools (e.g. the Valjevo Gymnasium, School of St. Sava from Pirot etc., author's note). However, the scientific basis from which a diverse and rich fund of museum objects will be formed over time was established thanks to the dedicated work, research and collection of materials by botanist Josif Pančić and his followers Jovan Žujović, Petar Pavlović and Živojin Jurišić.

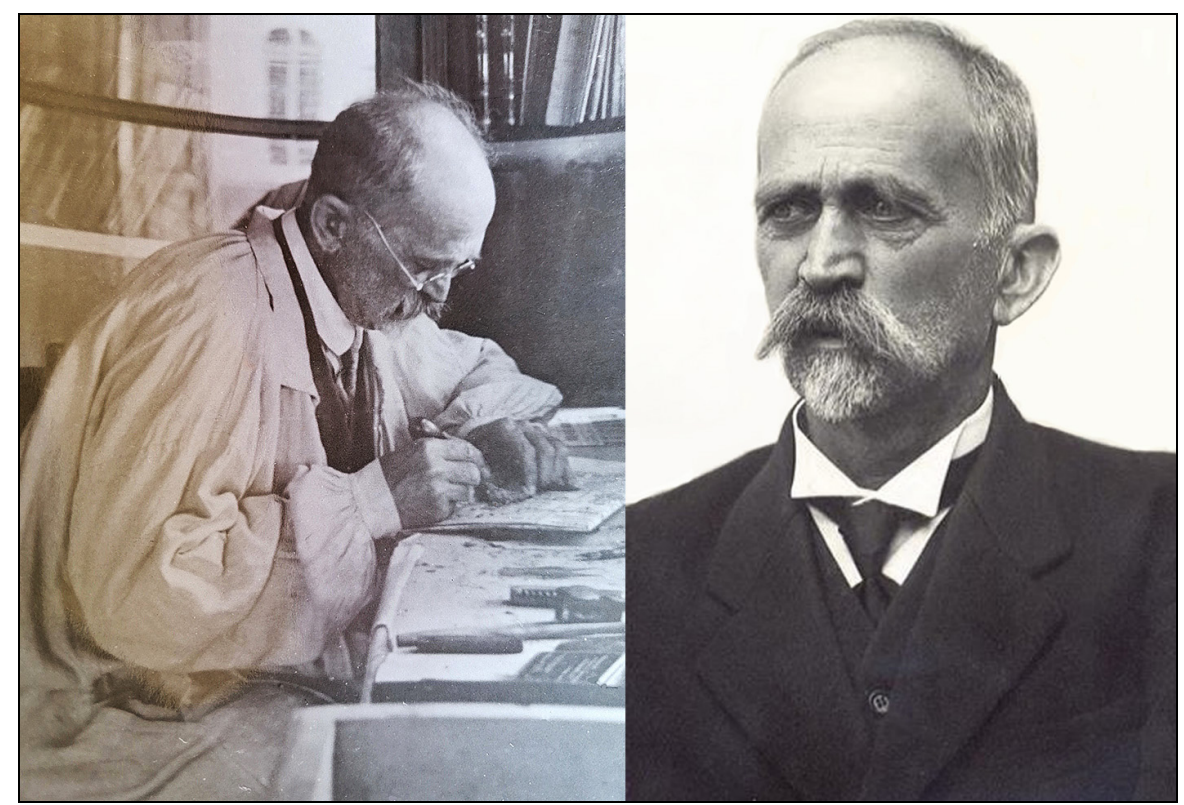

Fig. 6. - Petar S. Pavlović (1864-1938), professor of geology and mineralogy at the Second Belgrade Gymnasium. Academician, geologist, paleontologist and malacologist, founder and first director of the Museum of the Serbian Land (archive of P. Stevanović).

In the first half of the $19^{\text {th }}$ century, research into nature and natural resources in Serbia was stimulated for two reasons: the state's intention to develop and expand the national economy, primarily mining and geology, and the growing interest of European scientists in discovering a terra which was still quite incognita. The first written documents from this time come mainly from foreign naturalists ${ }^{2}$ who traveled through Serbia (Jović 2008;

2 Mining engineer Sigismund/Siegmund August Wolfgang von Herder (1776-1838), Austrian geologist, "father" of European geology Ami Boué (1794-1881), French geologist and geographer Auguste Viquesnel (1800-1867), Austrian geologist Frantz Toula (1845-1920), Hungarian geologist József Szabó de Szentmiklós (1822-1894), German geologist Bernard von Cotta (1808-1879), Hungarian geologist Antal Koch (1843 -1927), Hungarian botanist and entomologist Emerich Frivaldszky von Frivald (1799-1870), German botanist and geobotanist August Heinrich Rudolf Grisebach (1814-1879). 
Dinić 2012). Since their research was not rich in data, it was only with the arrival of Josif Pančić in Serbia, in 1846, that detailed systematic studies of nature and natural resources began.

Pančić is rightly considered the founder of natural science school of thought. He was a medical doctor who became a botanist, the first and most important in Serbia (Figure 7). He was the first to study nature, devise scientific terms for plant and animal organs and geological phenomena using words from the vernacular language, and was the first to warn about the need to be wise when dealing with nature. Gifted, hardworking and methodical in whatever task he undertook, he started collecting natural objects and founded the Botanical Garden and the Cabinet of of Natural Sciences (Žujović 1889). He also founded the first departments, equipped classrooms and taught the first generation of famous naturalists. Although he did not live to see the establishment of the Natural History Museum, the first Museum collections consisted of specimens of plants, minerals, rocks and fossils that were collected by Pančić, his students and his followers for the Natural History Cabinet of the Great School. These specimens represented the scientific basis from which a diverse fund of natural science objects will emerge over time (Vasić \& Niketić 2014).

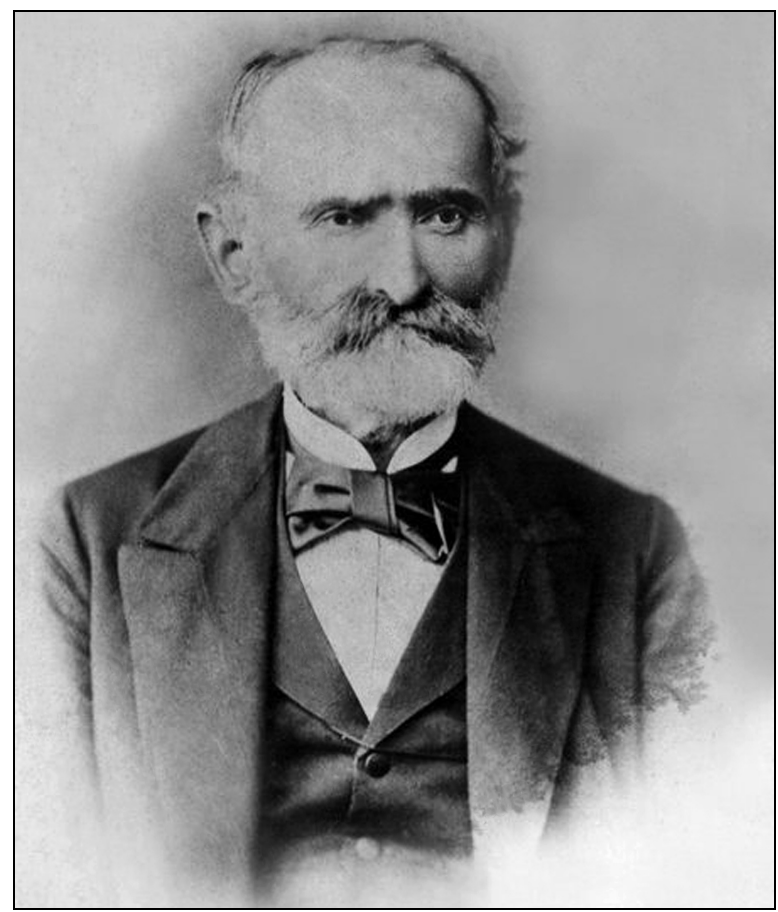

Fig. 7. - Josif Pančić (1814-1888), founder of natural sciences in Serbia and the first president of the Serbian Royal Academy (photo: Serbian Academy of Sciences and Arts). 
There are indications that certain items from the Museum of Rarities (daily newspaper Novine Serbske 1852) - founded by doctor Emerich Lindenmeier and surgeon Florian Birg within the Military Hospital in Belgrade in 1844, as they collected specimens of various pathological anomalies in humans and animals, "historical antiquities" as well as rock and ore samples - were at some point also transferred to the Museum. It is believed that the Museum of Rarities at the Military Hospital was the first state museological institution in the Principality of Serbia, formed to serve the development of medicine and natural sciences and the education of future youth, at the time when certain parts of Serbia were just liberated from the Turks and had no medical schools or faculties (Jovanović Simić 2006). The museum at the Central Military Hospital in Palilula was disbanded in 1862-63.

The Museum library, one of the oldest scientific libraries in Serbia, was officially founded in 1903. The first data on library and publishing activities date back to 1899 , when the Museum bought from professor Sima Trojanović almost the entire special edition of the publication titled "On Bears". The initial fund, which was also the first large contribution to the Museum library, was obtained from the family of professor Lazar Dokić (Figure 8), whose members donated a complete professional library following his death (Mučalica-Milanović 2003).

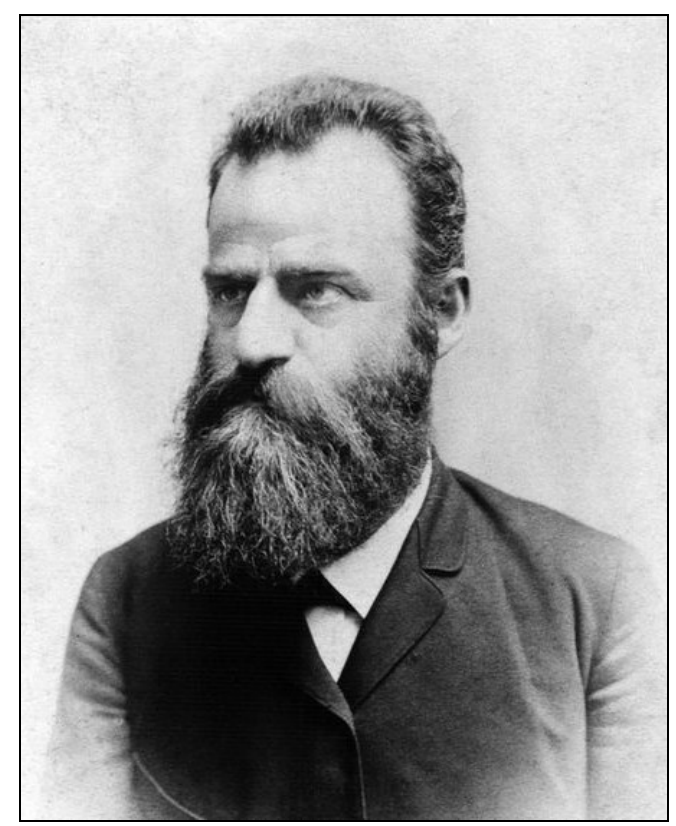

Fig. 8. - Lazar Dokić (1845-1893), medicine doctor, zoologist, professor at the Great School, President of the Council of Ministers and Minister of Education and Church Affairs (photo: Serbian Academy of Sciences and Arts). 
In its initial years, the Museum did not have a sufficient number of experts, or any funds. Director Petar Pavlović, curators Dušan Stojićević and Živojin Jurišić and the preparator Dobrivoje Stojadinović worked with the occasional help of professors Nikola Ranojević and Vladimir Petković.

Dušan Stojićević (1866-1939, Figure 9), a professor at the First Belgrade Gymnasium, spent 34 years at the Museum, first as a curator and zoologist (1903-1926), and then as its director (1926-1937). He researched the fauna of Serbia and Macedonia, mainly spiders, birds and fish. His works on the popular names of fish (1927), the first spiders in Serbia (1929), new birds (1932) and the scientific names of Serbo-Croatian birds (1938) were published in the special editions of the Museum. Dobrivoje Stojadinović (1882-1959, Figure 9), known among museologists by the nickname "čika Doša" (uncle Doša), was the Museum's first preparator and collector of geological and biological materials, administrator and librarian. He selflessly assisted prominent naturalists of that time such as Petar Pavlović, Jovan Žujović, Svetolik Radovanović, Jelenko Mihajlović, Jovan Cvijić, Vladimir Laskarev, Sava Urošević, Dimitrije Antula, Vladimir Petković and Dušan Stojićević, in their work. Diligent and frugal, he would collect anything he would come across and was able to carry - specimens of plants, samples of rocks, and fossils - and would then conserve them, to the extent that is absolutely unimaginable in today's terms (Stevanović 1960). After the retirement of Dušan Stojićević in 1937, he was the only employee of the Museum to take care of all collections and the library.

Živojin J. Jurišić (1863-1921, Figure 9), a high school professor, botanist and founder of the Serbian Botanical Society, was one of the first collaborators in the construction of the Museum, a long time museum treasurer and the first curator of the Botanical Department. He was not only the last, but also the most devoted student of Josif Pančić and his assistant in the Botanical Cabinet at the Great School (Pavlović 1922). He studied the flora of Serbia and other Balkan countries and collected material for the folk terminology of plants, which he later used in two botany textbooks intended for older high school students. As a great expert of plants and animals, he supplemented the dictionary of Vuk Karadžić with appropriate terms. Nikola Ranojević (1869-1922), a botanist and professor at the Second Male Gymnasium in Belgrade, was an expert at the Ministry of National Economy of the Kingdom of Serbia and the first head of the Agricultural and Chemical Experimental Station in Topčider, where he founded a laboratory for studying plant diseases. He was appointed honorary curator of the Botanical Department of the Museum of the Serbian Land. His collection of fungi and the entire library were destroyed during the First World War, while the only preserved mycological specimens, collected at the end of the $19^{\text {th }}$ and the beginning of the $20^{\text {th }}$ 
century, are currently kept in the Natural History Museum. Vladimir K. Petković (1873-1935, Figure 9) was a professor of natural sciences at the Theological Seminary of St. Sava (Bogoslovija Sveti Sava), professor of geology, rector of the University of Belgrade, member of the Serbian Royal Academy and founder of the State Geological Institute (today: Geological Survey of Serbia). He is considered the most competent expert in geology and tectonics of eastern Serbia as well as the Cretaceous formations in Serbia. He was the head of the Geological Institute of the University of Belgrade, editor of the journal "Annales Géologiques de la Péninsule Balkanique" (Geološki anali Balkanskoga poluostrva) and a long-term associate of the Museum.
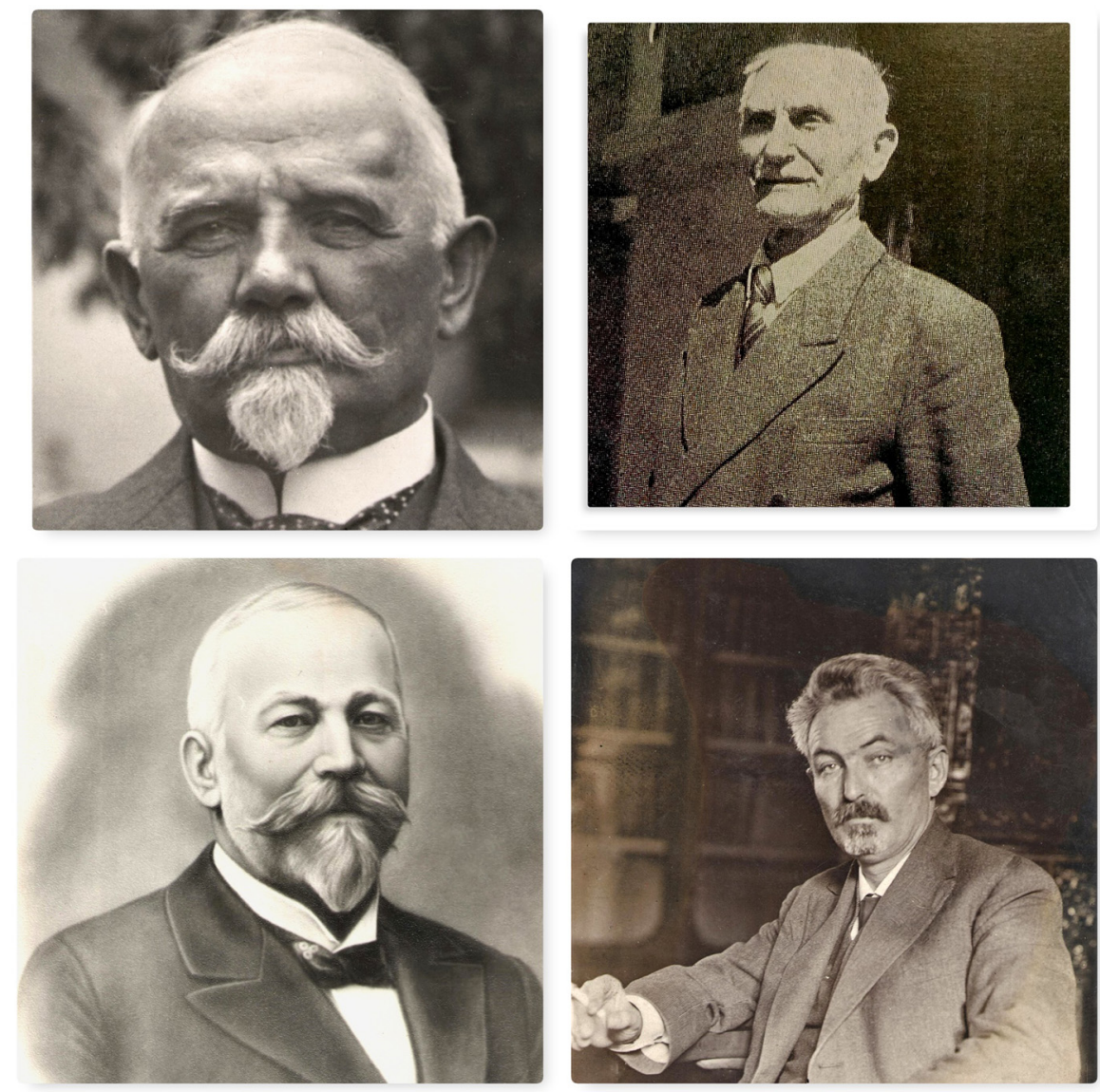

Fig. 9. - Dušan Stojićević, Dobrivoje Stojadinović (upper row), Živojin J. Jurišić, Vladimir K. Petković (photo library of the Natural History Museum, photo: A. Maran Stevanović).

During the first decade of operation, the Museum fund was enriched mostly with specimens and collections donated by eminent naturalists such 
as Svetolik Radovanović, Dimitrije Antula, Nikola Ranojević, Nedeljko Košanin, Dragutin Gorjanović-Kramberger, Jovan Cvijić, Mihailo Petrović (Mika Alas) and many others.

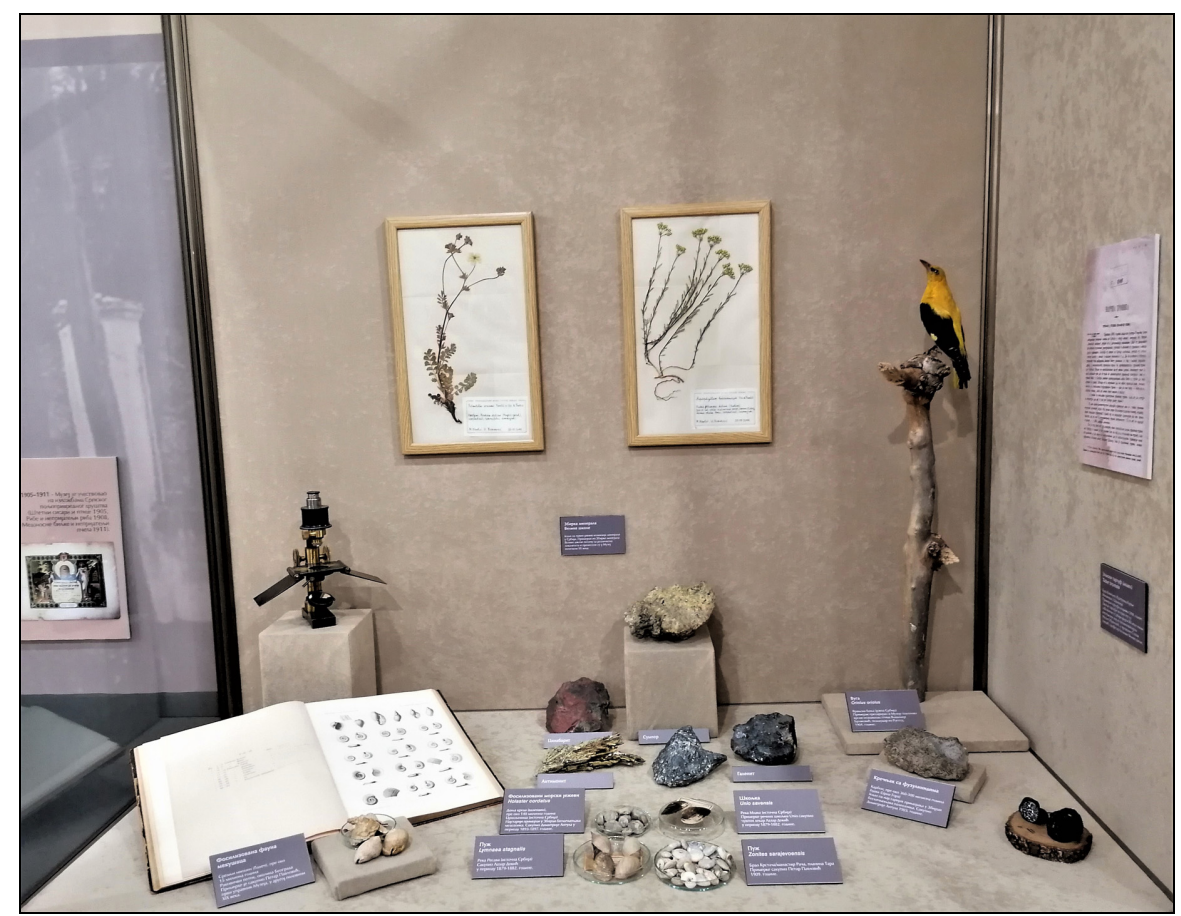

Fig 10 - The oldest specimens in the Museum's collections, detail from the exhibition A Story About Us, Gallery of the Natural History Museum, December 2020 (photo: A. Maran Stevanović).

The first field excursions were organised in the spring and summer of 1904, with the intention of adding new materials to collections: in the area surrounding Belgrade, between Pirot and Midžor, in Timočka Krajina (Figure 11), near Jagodina (Ravanica and Manasija), in the vicinity of Prokuplje and in western Serbia (Krupanj, Ljubovija, Bajina Bašta) (Pavlović 1905). Today, field research and collection are still the basic forms of acquisition of museum objects.

The first exhibition was opened to the public on 7 September 1904, as part of the celebration of the centenary of the First Serbian Uprising and the coronation of King Petar I Karadjordjević. The gathering was greeted by Jovan Žujović, Chairman of the Board for the Construction of the Museum. This is where he made his famous address, whose one part was dedicated to the vision of the Museum: "... In the realised Serbian ideal, we dream our naturalistic dream: We see a grand and glorious building worthy of grandeur and virtue of the Serbian people. In that building, we see the 
Museum of all among which Serbs live - soil, stones, ores, plants and animals, everything that by nature affects the life and progress of Serbs. In the Museum, we see swarms of students learning, in all this and through all this, to love their homeland; we also see crowds of simple people, thirsty for science and education, and - through them - for freedom and prosperity. Our dream will be realised by our students" (Pavlović 1905).

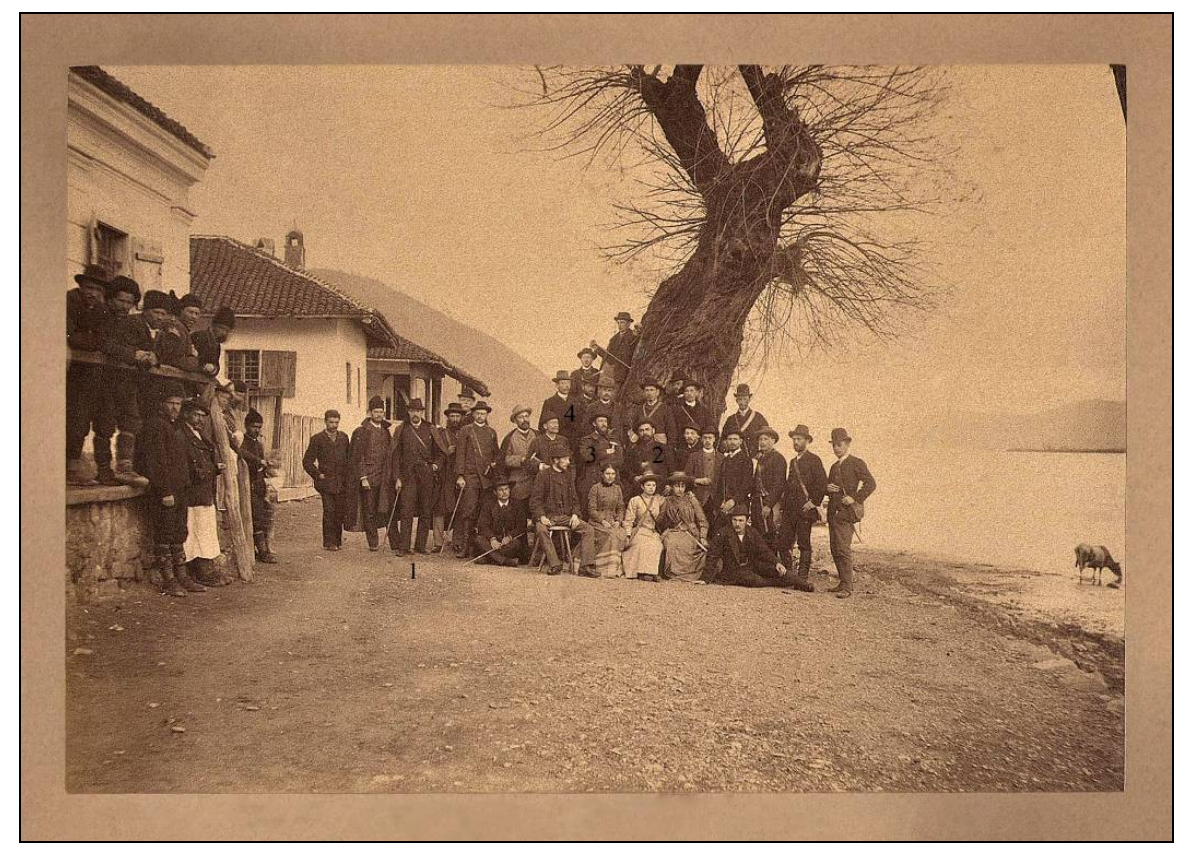

Fig. 11. - Field excursion in Timočka Krajina: Dobra on the Danube, Djerdap gorge (archive of Petar Stevanović).

This exhibition, which remained open to the public until 1938 although interrupted during the Balkan Wars and the First World War, was visited by Bulgarian geologists Georghi Nikolov Zlatarsky and Stefan Bonchev, Croatian naturalists Spiridon Brusina, Dragutin Gorjanović-Kramberger and Oton Kučera, archaeologist Miloje Vasić, painter Marko Murat, cartographer of the Geographical Institute of the Great School Radoje Dedinac, student Gavrilo Princip from Sarajevo, high school student Moša Pijade and many others. During the period 1905-1911, the Museum actively participated in exhibitions organised by the Serbian Agricultural Society (Harmful Mammals and Birds, 1905; Fish and Enemies of Fish, 1908; Honey Plants and the Enemies of Bees, 1911).

The financing of Museum activities from the state budget began only in 1908 (Pavlović 1909). The Museum received great financial help in 1910 from the Board of the Veliminarium, the endowment of Velimir Mihailo 
Todorović, illegitimate son of Prince Mihailo Obrenović (Pavlović 1911). These funds (2.000 dinars in gold) were used to purchase and complete multi-volume expert literature on recent gastropods, and to print certain museum editions.

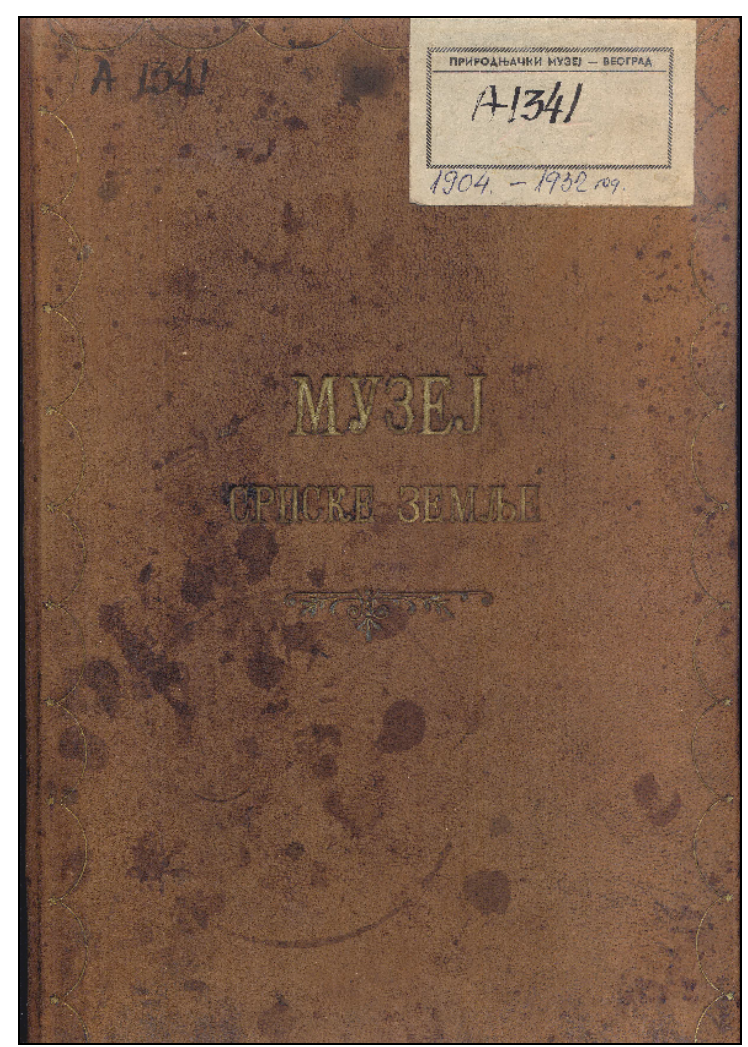

Fig. 12. - Visitor's book of the Museum of the Serbian Land, 1904-1938 (photo: A. Maran Stevanović).

In 1907, Petar Pavlović organised the first educational-pedagogical excursion for teachers and students of the Teaching School in Jagodina, to Crni Vrh, where he lectured the participants on how to collect, prepare and conserve various objects of natural science (Pavlović 1908).

The main activity of the Museum encompassed four departments: 1) mineralogical-mining, 2) geological-paleontological, 3) prehistoric, and 4) zoological. Due to the lack of space and the dampness of rooms, there was no botanical department as most of the botanical collections were never transferred from the Great School to Stevča's endowment. In 1912, a small courtyard building of the former phytopathological department of the Agricultural Experimental Station in Vračar was obtained for their accommodation, thanks to the Ministry of Education and Church Affairs 
(the facility next to the Astronomical and Meteorological Observatory, today the Meteorological Observatory in Karadjordje's Park, author's note). In addition to the botanical material, some of the "precious mammal fauna" was transferred there as well (Pavlović 1912).

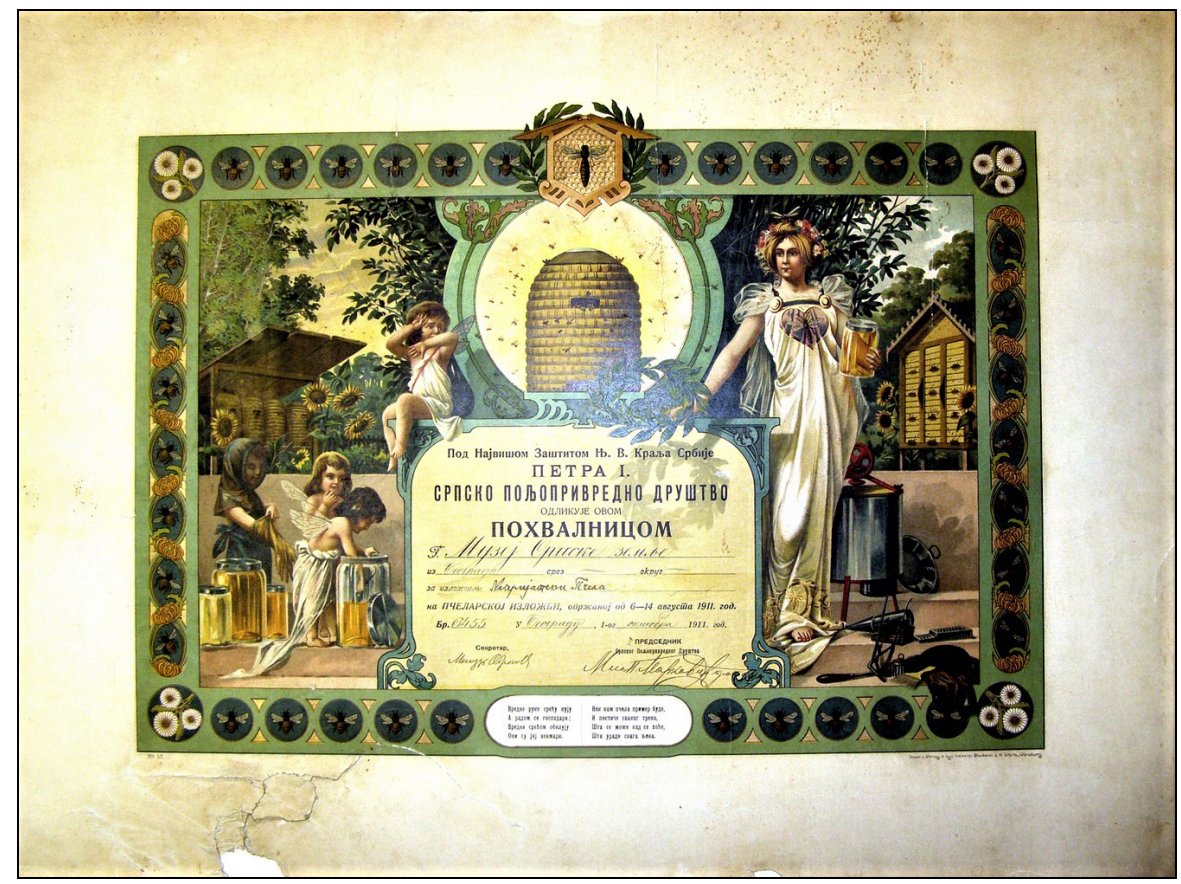

Fig. 13. - A commendation from the Serbian Agricultural Society for participation at the exhibition in 1911 (archive of the Natural History Museum).

Work of the Museum was completely interrupted during the Balkan Wars (1912-1913) and during the First World War (1914-1918), when the few existing museum staff members - director, curator and preparator were mobilised. Upon the order of the Minister of Education of 1914, all valuable objects and documents were packed, labeled and transferred from the Museum to the "Green Gymnasium" in Niš. On that occasion, a chest containing the meteorites from Sokobanja, Jelica and Guča was dispatched to Niš. However, it was taken to Kraljevo by mistake and buried in the yard of a private house. The meteorite from Guča was never seen again (Pavlović 1920).

During the occupation, Stevča's building was used to accommodate soldiers of the German drivers' department who used museum furniture, inventory lists, letters, documents and books whever they needed to start a fire. The part of the library fund which contained rare publications suffered the most. In a letter to the Ministry of Education and Church Affairs, Petar Pavlović stated that before the war the Museum library had 1.090 items, the 
value of which was at least 32,000 (then) dinars, and that 155 books were destroyed during the occupation (ANHM 3/1919; 4/1919). The building in Vračar, which housed herbarium material, a botanical library, valuable zoological material, optical instruments and preparation tools, was completely devastated and parts of the collections of mammals and birds were demolished or stolen (Pavlović 1920).

In the period before the First World War and between the two World Wars, the most significant field research was conducted in the area of Belgrade, today's Vojvodina, eastern, southern and Old Serbia (Raška, Kosovo and Metohija, part of Vardar and Aegean Macedonia). The fossilbearing sites of Neogene age discovered in the wider vicinity of Belgrade, in Rakovica, Vrčin and Beli Potok, stand out in terms of scientific importance. Petar Pavlović and Dobrivoje Stojadinović participated in the exploration of these localities and were joined in the second half of 1920 by a Russian emigrant, professor Vladimir Dimitrijevič Laskarev (Vladimir Dimitriyevich Laskarev).

One of the best studied profiles was discovered in Vrčin, during the construction of the Belgrade-Mala Krsna railway, on the right bank of the Karagač stream. Various specimens of endemic malacofauna, collected from the old excavation site of sandy-gravel sediments which were used to fill the railway, are now kept in the collections of the Natural History Museum and the Paleontological Museum of the Faculty of Mining and Geology in Belgrade. Among the fauna found in the Karagač stream, Petar Pavlović determined and described representatives of 57 new species of bivalves and gastropods, for science. Thanks to Petar Stevanović, the Karagač site later gained world recognition (1951) as a stratotypic site of Upper Pannonian - Serbien sediments for the entire area of Central Paratethys. Equally important was the profile in Beli Potok on the southeastern slopes of Avala, which was discovered between the two World Wars. In addition to the rich fauna of mollusks, fossilized plant remains were also collected at this site and determined by the botanist Pavle Černjavski (Pavle Chernyavsky). These sites are important not only from the aspect of stratigraphic-paleontological research, systematics, evolution, taphonomy, paleogeography, paleoecology, and reconstruction of geodynamic events and changes that took place during recent geological history, but also as geoheritage objects of the wider Belgrade area.

The attention of the public was also attratced by two other fossilbearing sites - Beluška and Prevalac, not far from Veles (Veles valley, today's North Macedonia) (Figures 15 \& 16), where fossilised remains of representatives of "Pikermi fauna", named after the Pikermi site in the suburbs of Athens (Greece) where it was first found by the Scottish historian and Hellenist George Finley in 1836, was discovered. 


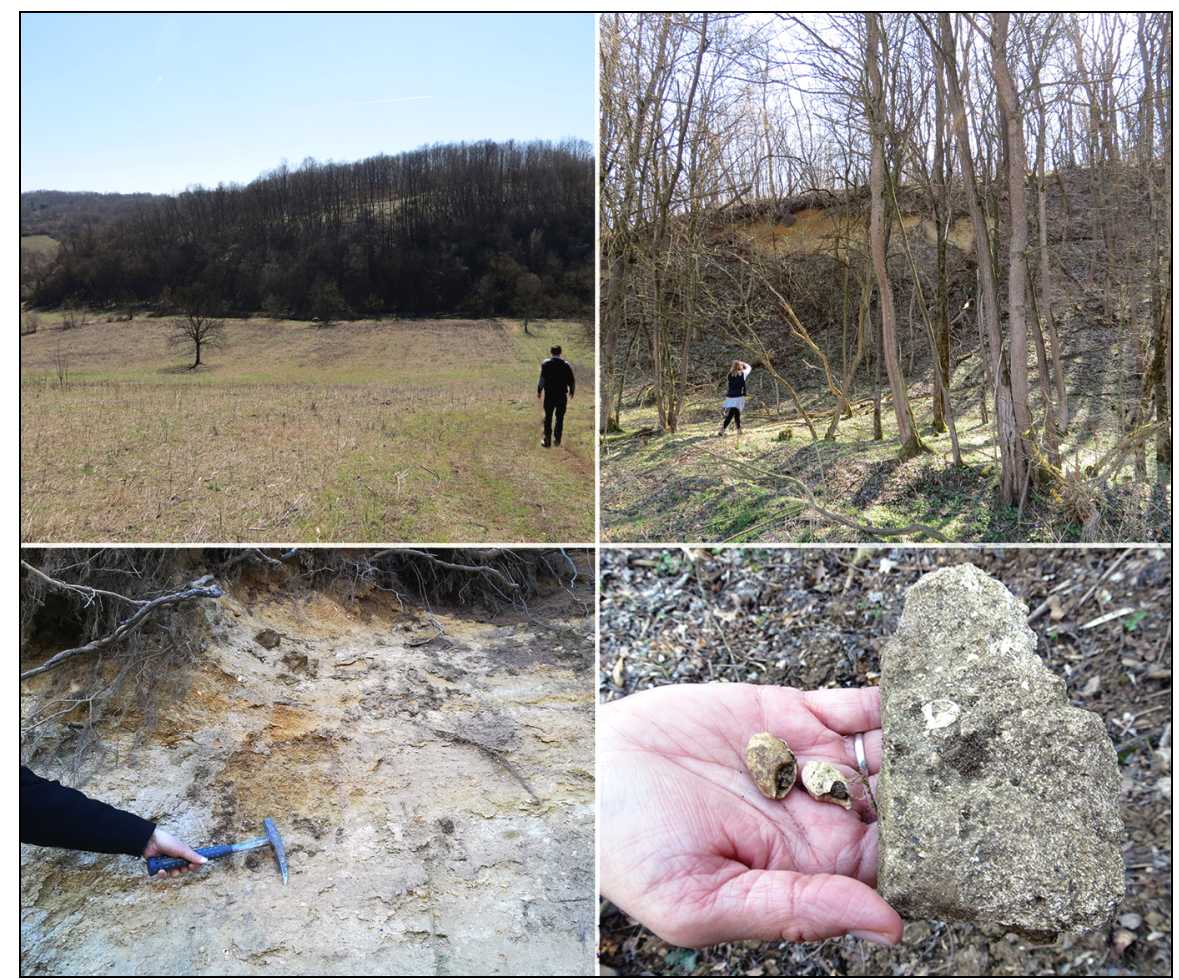

Fig. 14. - Fossil-bearing sandy sediments, Karagač locality (photo: Z. Stevanović \& A. Maran Stevanović).

Petar Pavlović, professors Vladimir Laskarev and Milan Luković with their associates, as well as museum preparator Dobrivoje Stojadinović, participated together in the excavation and study of the "Veles fauna", which researchers internally named after the place where it was discovered. Material was collected during the expeditions organised in the period 1922-1929: fossilised bones of large and small mammals, mainly representatives of mastodons, dinoteriums, horses, rhinos, antelopes, giraffes, deer, civets, hyenas, martens and primates. It is assumed that the appearance of mammals in this area was caused by the formation of steppe ecosystems during the Upper Miocene (MN12 - Turolian). In addition to mammals, fossilised remains of various species of birds, turtles, lizards and amphibians were discovered as well. In the Report to the Academy, Petar Pavlović noted that German soldiers came across this fauna by chance, while digging sand to fill roads and railways not far from Veles in 1917, although the credit went to the German engineer named Jungman, head of the prisoners' battalion (Pavlović 1922, pp. 11-13). Despite the fact that he studied the Veles fauna for years, Vladimir Laskarev never published his detailed 
findings because German professor Max Schlosser (1854-1932) was working on the same issue at that time. Laskarev only later became acquainted with his work. What is significant in relation to Vladimir Laskarev is the fact that in his note on the Veles fauna, published in the journal Geološki anali Balkanskoga poluostrva (1923), he did mention and explain the term Paratethys for the first time. At the meeting of the Serbian Geological Society, held on 10 April 1924, Laskarev promoted the term which was later widely introduced into world scientific literature and practice. Paratethys used to encompass the water area between the Alps in the West and the Dinarides in the South, the Carpathians in the East and the Rhodopes in the southeast, while the famous Pannonian Sea was one of its bays. Today's Mediterranean Sea is a relic of the former Paratethys.

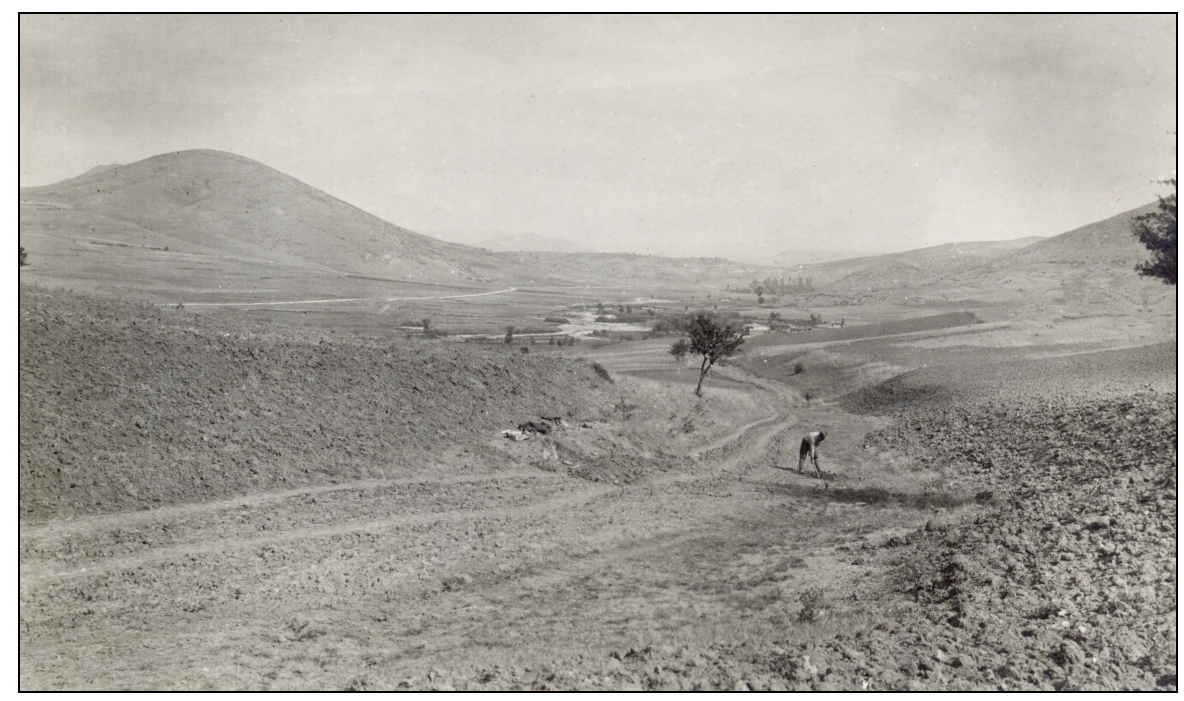

Fig. 15. - Fossiliferous sites Beluška and Prevalac, road Dolno Orizari-Vitanci, westwards of Veles (photo D. Stojadinović 1922; photo library of the Natural History Museum).

Collections of mammals, birds, insects, fish and molluscs, as well as the herbarium materials, were added between the two World Wars, thanks primarily to numerous donors but also to field exploration which was mainly financed from the curators' modest funds and facilitated by the participation of volunteer associates. Dušan Stojićević brought numerous specimens of insects, fish, amphibians and reptiles from his field excursions in Macedonia (around Skopje, Tetovo and Gostivar). There was significant exploration and collection of plants in the Vardar valley, around Veles, Ovča and Ježevo polje, in the vicinity of Štip, Kočani and Radovište, as well as around Belgrade. 


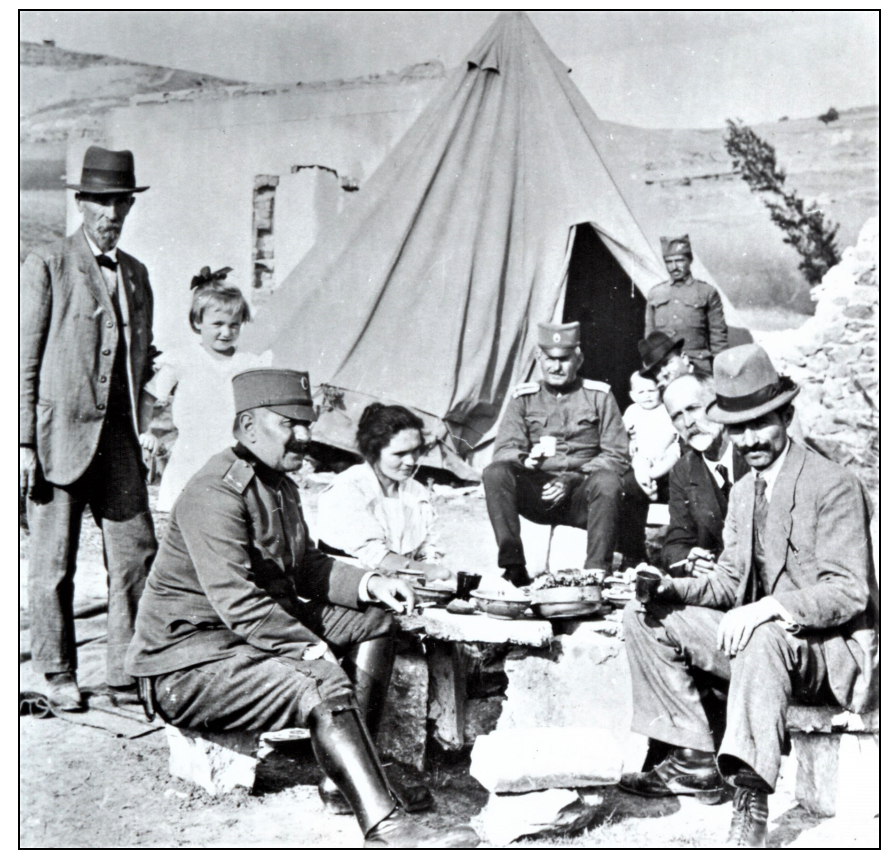

Fig. 16. - Vladimir Laskarev (left), Dobrivoje Stojadinović and Petar Pavlović (right), field camp, Veles surroundings, taken in 1922 (photo library of the Natural History Museum).

\section{THE FIGHT FOR SURVIVAL}

The Museum's director, Petar Pavlović, often pointed out to the competent authorities the insufficient size of the space and the humidity in Stevča's endowment. The Museum had at its disposal the ground floor of Stevča's house (Figure 17) - six rooms, the entrance hall, a workshop and an office, for the total surface area of 400 square metres - and a rented 60 square meter space in Dobračina Street which was used for additional workshops (Pavlović 1906). Objects and preparations, especially the zoological ones, had to be taken outside each year to dry out, and a lot of valuable material was ruined due to moisture. Although unsuitable, the exhibition part of the Museum of the Serbian Land covered 172 square metres.

In 1927, members of the Academy requested that the Ministry of Education and Church Affairs give the Museum a building “... because without a roof over our heads we cannot talk about anything else, and today's museum premises are similar to it being kept outside, in the field". It was noted in the 1929 Report that ".. this year too, the Museum was left without a comfortable building, its own or someone else's for that matter. 
Among other problems, the current gloomy and damp building did not make it possible for the work to develop as it should... and the infinit esimal amount assigned for maintenance and work is three and a half times smaller than what the Museum was receiving back in 1912" (Stojićević 1929).

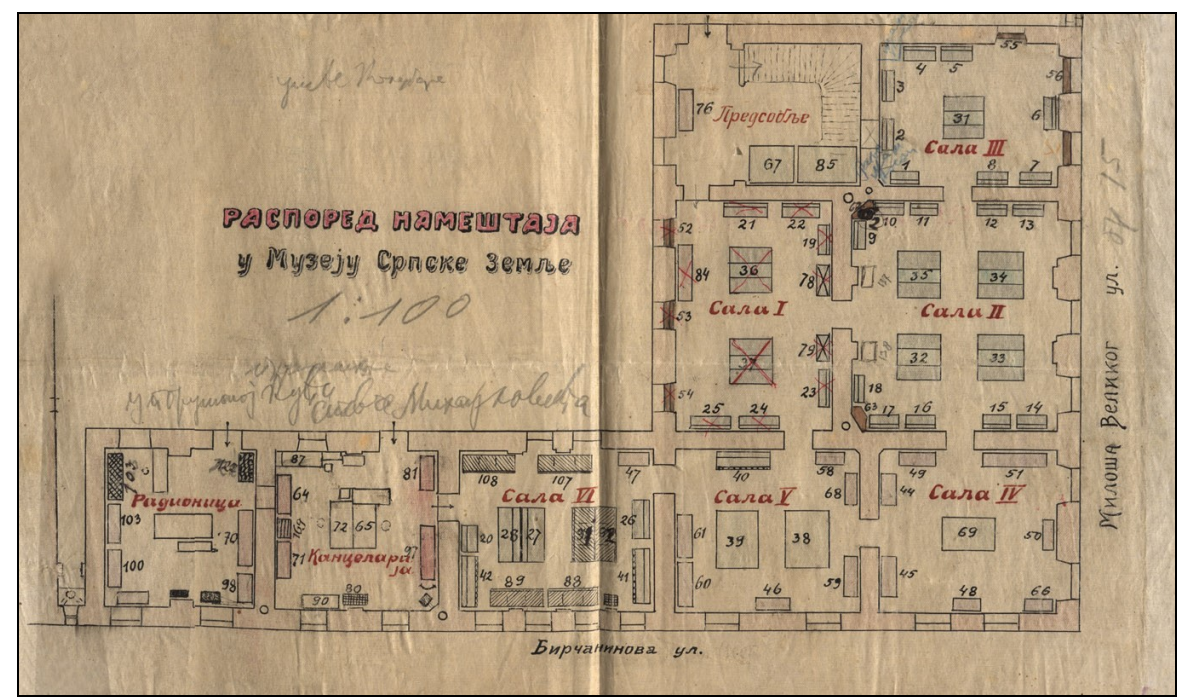

Fig. 17. - The layout of the premises and furniture of the Museum of the Serbian Land in the endowment house of Stevča Mihailović (archive of the Natural History Museum in Belgrade).

In the period 1930-1937, out of six employees that were officially registered in the budget of the Ministry of Education, only two experts worked in the Museum: director/curator Dušan Stojićević and preparer Dobrivoje Stojadinović. Former director Petar Pavlović continued to help even though he was retired. "... With this number of staff and in a building like this, there can be no talk of any serious scientific work. We merely exist. We are maintaining the collections to save them from decay, to the extent possible, and welcoming visitors..." (Stojićević 1937).

In 1937, Borivoje Drobnjaković (1890-1961), ethnologist, anthropogeographer and museologist, was appointed acting director of both museums. Noting the situation in the Museum ${ }^{3}$ he dispatched an urgent communication to the Ministry and new curators were hired in 1938: geologist Petar Stevanović, zoologist Milutin Radovanović and botanist Pavle Ivanovič Černjavski (Pavle Ivanovich Chernyavsky).

${ }^{3}$ The director of the Museum of the Serbian Land, Dušan Stojićević, retired in 1937 and preparator Dobrivoje Stojadinović, in addition to his regular duties, took over all the administrative and utility tasks, as well as the care of all the museum collections and the library. 
Due to the demolition of the Stevča Mihailović's endowment and the planned construction of a new museum complex on the same plot, Minister of Education Dimitrije Magarašević issued a decision on 3 May 1938 to temporarily house the Ethnographic Museum and the Museum of the Serbian Land in two buildings in Vračar, on the corner of Njegoševa and Kneginje Zorke streets (ANHM 1/1938). In July 1938, the Museum of the Serbian Land moved into the building in Njegoševa St. 51, while the Ethnographic Museum was awarded a courtyard building with an entrance from Kneginje Zorke St. 57 (ANHM 1/1938). Both buildings originally belonged to the private school of Professor Vladimir Zdelar (1904-1911), and then to the First Women's Real Gymnasium (1911-1938).

In 1904, professor Vladimir Zdelar was allowed to open and operate, at his own expense, an "incomplete four-year high school in Belgrade", which was located in Njegoševa Street and had spacious and bright classrooms, as well as a library with more than 700 books" (Vicić \& Vicić 2008) (Figure 18). Between the two World Wars, the First Women's Real Gymnasium (today the Fifth Belgrade Gymnasium, author's note, Figure 19) operated at this location and was attended, among others, by the famous painter Nadežda Petrović, while writers Desanka Maksimović and Jovanka Hrvaćanin, as well as journalist, philosopher and choreographer Marija Maga Magazinović, taught there.

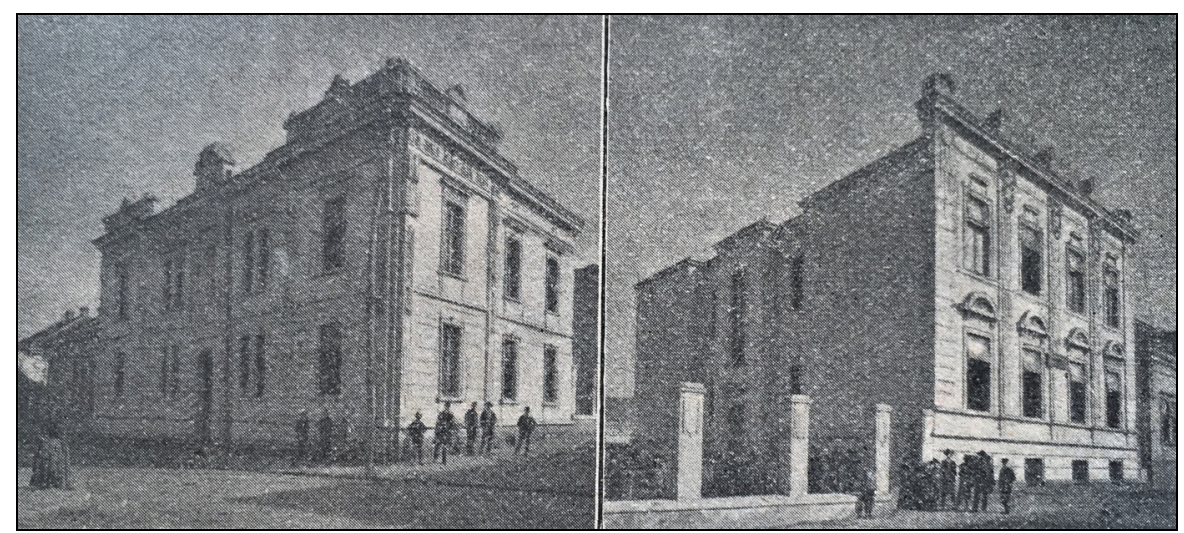

Fig. 18. - Vladimir Zdelar School, recorded in 1907/1908 (archive of the Pedagogical Museum in Belgrade).

Stevča's endowment was demolished in 1938, but the idea of a new building was never realised. The competition for conceptual sketches for the new structure was announced in 1938 (ANHM 1/1938). On 2 August 1939, an article was published in the daily newspaper "Vreme", together with the sketch of the future Ethnographic Museum, whose construction was to begin in September that year. Then came the World War II, and after the liberation buildings of other purposes and under different 
ownership were erected on the endowment plot. In 1951, the Ethnographic Museum was moved to the building of the former Belgrade Stock Exchange on Students' Square, while the Natural History Museum remained in its temporary space at the same address, in Njegoševa Street.

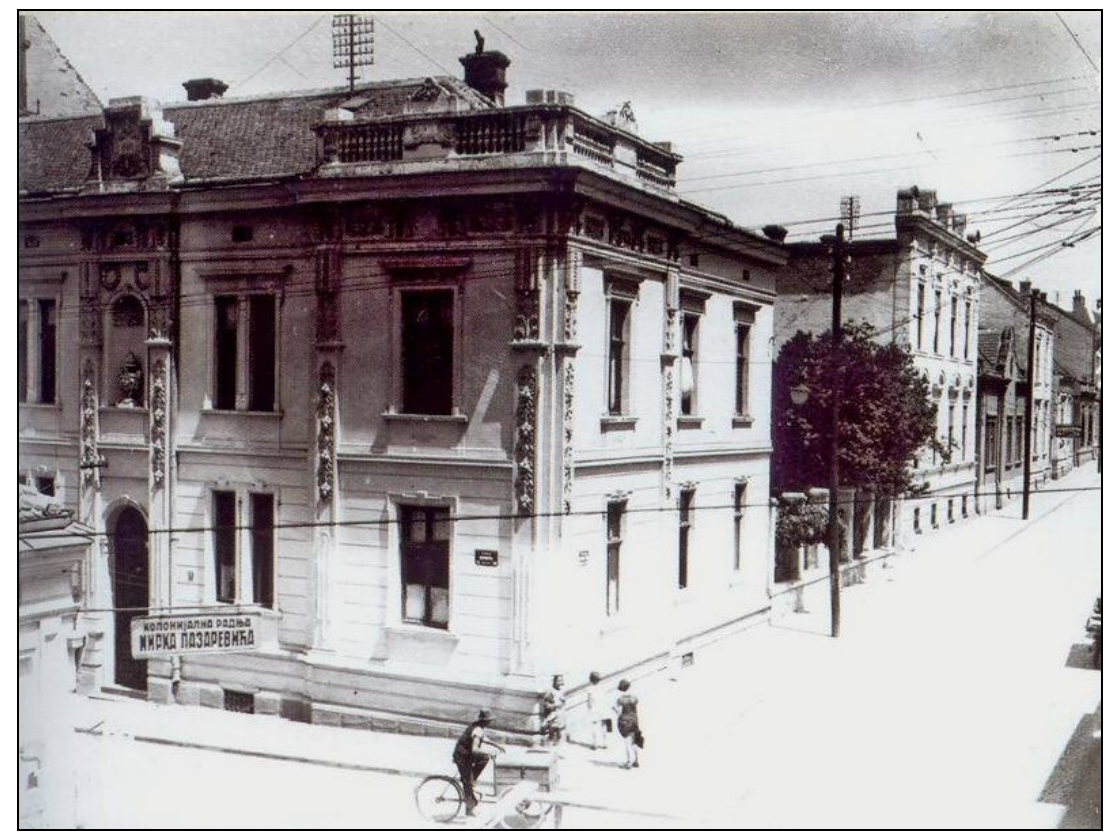

Fig. 19. - The building of the First Women's Real Gymnasium, recorded in 1938 (archive of D. Gajić, Facebook forum "Once upon a time there was one Belgrade").

Diaries, notes and reports on the work of the Geological-Paleontological and Mineralogical-Petrological Departments of the Museum for the period 1939-1945 are now kept in the archives of Petar Stevanovic ${ }^{4}$, who at the time was in charge of the respective collections. From his notes, it is possible to track the creation of new temporary inventories, the review and selection of the extensive legacy of Petar Pavlović, and the condition of the geological collections. It was established that most fossils, minerals and petrological samples were damaged by moisture in Stevča's building, especially the accompanying labels which were almost completely illegible, and that the new accommodation was not suitable either: apart from moisture, it lacked space for storing materials, as the Museum was sharing

${ }^{4}$ Petar Stevanović (1914-1999) was a geologist and naturalist, curator of the Museum of the Serbian Land, university professor, member of the Serbian Academy of Sciences and Arts. At the celebration of the centenary of the founding of the Natural History Museum (SASA 1995), as a sign of gratitude for the great contribution to its home institution, the Museum staff presented him with the title of "Lifelong Curator". 
storage space with the Ethnographic Department. In 1939 and 1940, by the decision of director Drobnjaković, Petar Stevanović paid expert visits to the National Museum in Sarajevo, the Geological and Paleontological Museum in Zagreb and the National Museum in Ljubljana, in order to get acquainted with the arrangements of various museums in the region (Figures $20 \& 21$ ).

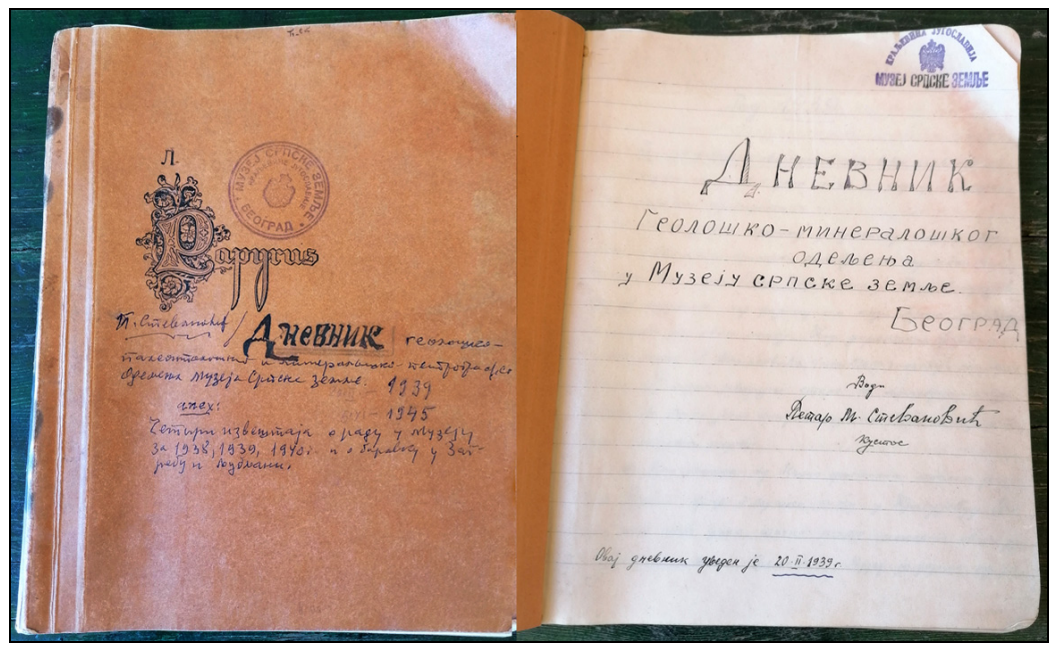

Fig. 20. - Diary of the Geological-Paleontological and MineralogicalPetrological Departments of the Museum of the Serbian Land for the period 1939-1945 (archive of P. Stevanović; photo: A. Maran Stevanović).

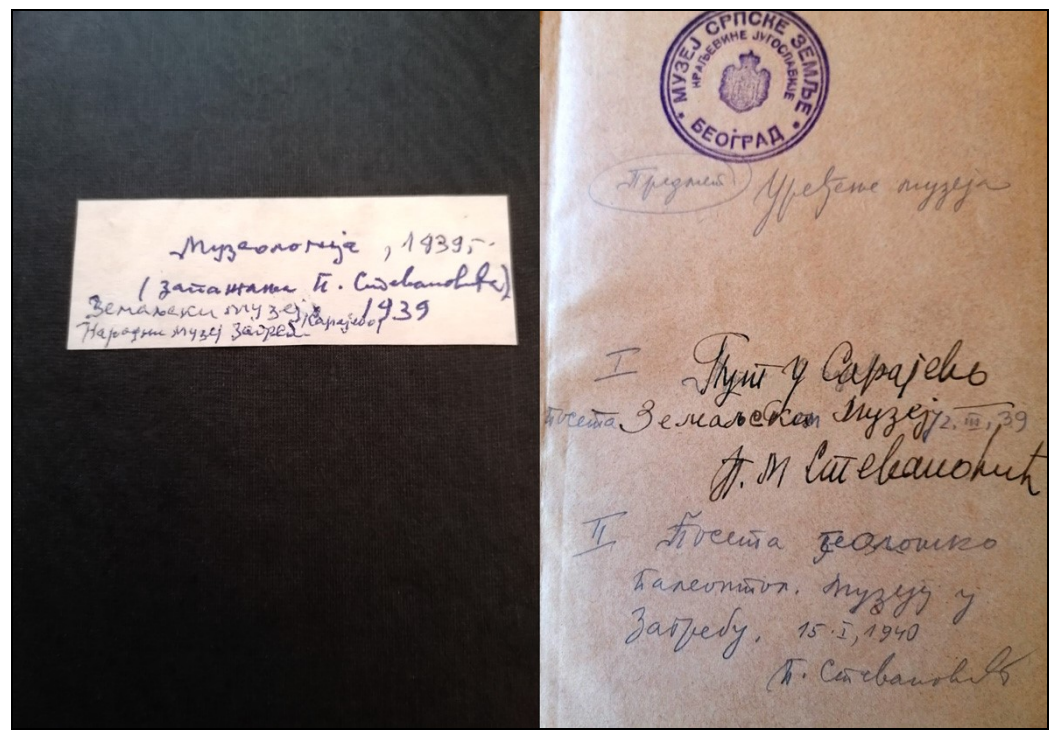

Fig. 21. - Notebook on museum organisation, expert visit of P. Stevanović to the National Museum in Sarajevo and the National Museum in Zagreb, March 1939 - January 1940 (archive of P. Stevanović; photo: A. Maran Stevanović). 
For years, the Museum was selflessly helped by many renowned scientists, primarily Russian emigrants: academician Vladimir Dimitrijevič Laskarev (Vladimir Dimitriyevich Laskarev, 1868-1954), professor at the Faculty of Mining and Geology of the University of Belgrade and a great Russian/Serbian geologist and paleontologist (Figure 22); Nikola Aleksija

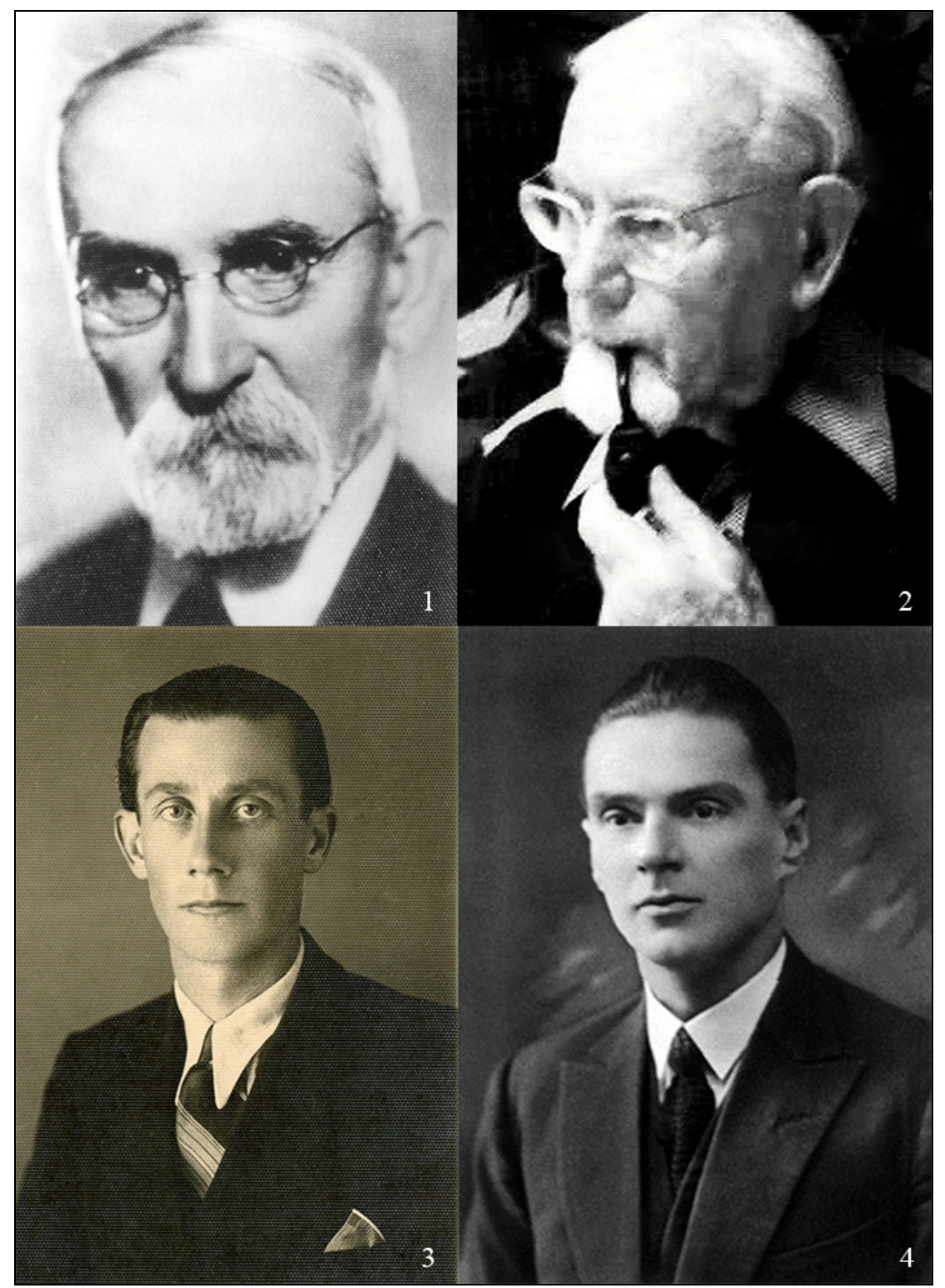

Fig. 22. - Russian emigrants, associates of the Natural History Museum: Vladimir Dimitrijevič Laskarev (1), Sergej Dimitrijevič Matvejev (2), Oleg Sergejevič Grebenščikov (3), Igor Andrejevič Rudski (4). 
(?) Muravjoj (Nikola (Aleksija?) Muravyov, 1894-1945), teacher at the Berane Gymnasium, botanist and zoologist; Igor Anrejevič Rudski (Igor Andreyevich Rudsky, 1897-1944, Figure 22), professor at the Kragujevac Gymnasium and founder of phytocenology in Serbia; Oleg Sergejevič Grebenščikov (Oleg Sergeyevich Grebenshchykov, 1905-1980, Figure 22), geobotanist, ballet soloist of the National Theatre in Belgrade, choreographer and composer; Igor Sergejevič Grebenščikov (Igor Sergeyevich Grebenshchikov, 1912-1986), biologist and geneticist, theatre actor and poet; Vladimir Emanuilovič Martino (Vladimir Emanuilovich Martino, 1889-1961), zoologist; Lav Rajevski (Lav Rayevski, 1910-2001), botanist; and Sergej Dimitrijevič Matvejev (Sergei Dimitriyevich Matveyev, 19132003, Figure 22), biologist, ornithologist and ecologist.

The period 1940-1941 was marked by the change of generations and the beginning of World War II. Preparator Dobrivoje Stojadinović retired and two new curators were hired: botanist-mycologist Vojteh Lindtner (Vojtech Lindtner) and zoologist Boris Mihailovič Petrov (Boris Mihailovich Petrov). In anticipation of the war, museologists packed and secured the objects, libraries and archives and placed them in the basements of buildings in Njegoševa St. 51 and Kneginje Zorke St. 57 (Vlahović 1953). Sergej Matvejev (2006) wrote down that during the bombing of Belgrade, which took place on 6 April, an unexploded bomb fell through the tin roof of the Museum, causing no damage other than breaking windows and scattering glass fragments. In mid-April 1941, diary-keeper/assistant Milivoje Ivković and curator Petar Stevanović were arrested and imprisoned (ANHM 1/1942).

In October 1942, biologist Borivoje D. Milojević, one of the most prominent professors at the University of Belgrade, was appointed acting director of the Museum. In November of the same year, dr Dimitrije Miodragović's five-room apartment in Kneginje Zorke St. 66 was rented as additional accommodation for the collections (ANHM 1/1942). Pavle Černjavski, Boris Petrov, Vojteh Lindtner and Zorka Delić worked at the Museum during the occupation. In accordance with the directive of the then council of the Ministry of Education, museum activities were to be conducted in a "self-sacrificing manner", with strict respect of the working hours (ANHM 1/1942). Although the possibilities for field exploration were extremely limited, the collections were still being supplemented with entomological, zoological and botanical material collected in the vicinity of Belgrade, Šabac and Kragujevac, as well as with gifts from Museum associates Vladimir Martino, Oleg Grebenščikov, Igor Rudski, Lav Rajevski, Aleksandar Sigunov, Teodor Soška and many others. Work was also being done to arrange and protect the collections and compile inventory sheets, and initiatives were launched to pass decrees on nature 
protection and regulations and instructions for collecting and storing museum objects (ANHM 16/1942). Due to the absence of curator Petar Stevanović, who spent the war in the Osnabrück labour camp in Germany, Boris Petrov was temporarily taking care of the Geological and Paleontological Departments, with the engagement of Vladimir Laskarev and Zarija Bešić (Maran Stevanović 2014).

According to Professor Milorad Janković (1924-2002), who came to the Museum at the invitation of Pavle Černjavski and remained for seven years (1943-1950), a part of the war period was marked by a "lively museum activity", but also by numerous curators, associates and volunteers who decisively influenced his future scientific work and creativity (Kojić 1995). In 1944, the Anglo-American air force bombed Belgrade eleven times: three times in April, twice in May, once in June, once in July and four times in September. The building in Kneginje Zorke St. 66, where part of the Museum's collections were stored at the time, was hit during the bombing of 8 September 1944. On that occasion, curator Boris Petrov and his wife as well as several citizens were buried under the rubble, but managed to escape without any serious injuries (ANHM 1944).

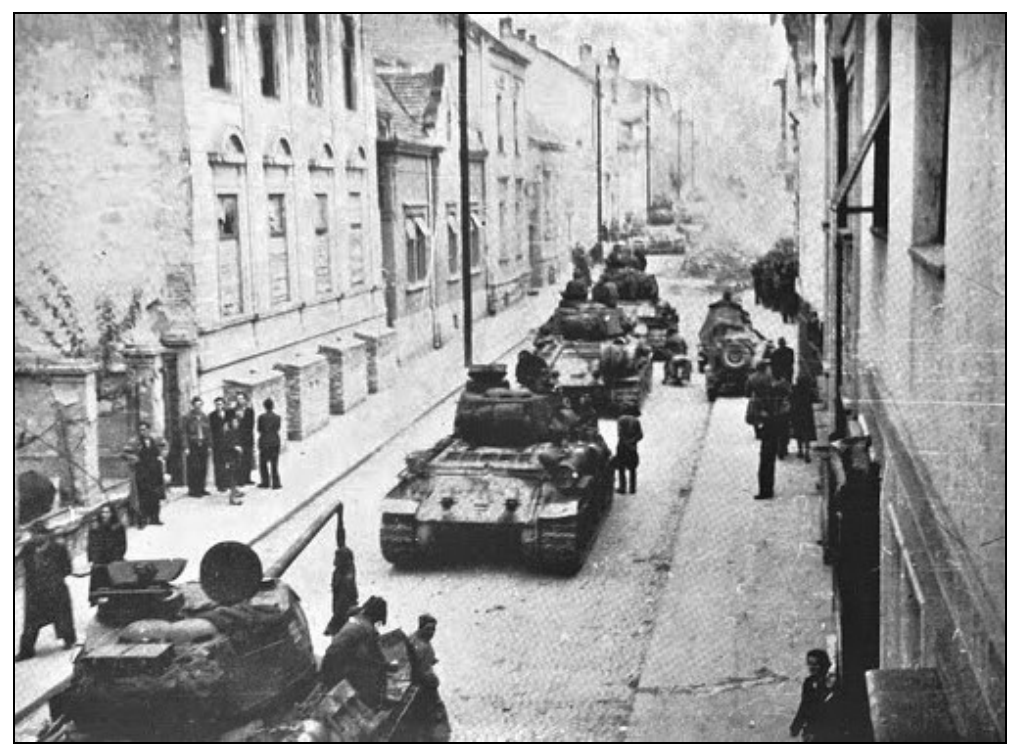

Fig. 23. - Red Army tanks in Kneginje Zorke Street, October 1944 (source: tankfront.ru).

The sorting, preparation, determination and revision of previously collected material continued in the post-war period. The Institute of Ecology and Biogeography of the Serbian Academy of Sciences was established as an integral part of the Museum in 1947 (Gojković 1954). New systematic paleontological, mineralogical and petrological exploration 
included, equally, both the curators and the museum associates: Petar Stevanović, Zarija Bešić, Velimir Milošević, Božidar Matejić, Vojislav Simić, Aleksandar Kostić, Milena Mihajlović, Živojin Petronijević, Aleksandar and Branislav Ćirić, Aleksandra Danilova, Borivoje Milaković, Nikola Pantić, Nadežda Krstić and Milorad Pavlović. Especially important were the studies of sedimentary rocks from different periods of geological history in eastern, western and southern Serbia, Kosovo and Metohija, Macedonia and Montenegro, as well as the research of alkaline basalt rocks, lamprophyre wires, crystalline shales and granitoids in Serbia.

Pavle Černjavski, Boris Petrov, Vojteh Lindtner, Sergej Matvejev, Vladimir Martino, Aleksandar Sigunov, Živko Adamović, Vojislav Nikolić, Nikola Diklić, Djordje Mirić, Velika Jovanović, Zagorka Pavlović, Simeun Grozdanić, Milorad Janković, Pavle Vukasović, Slobodan Glumac, Amalija Matvejev, Danica Čubrilović and Živomir Vasić greatly contributed to the knowledge of the flora and fauna of Serbia, as did many others. Extensive floristic, taxonomic, phytogeographical and ecological research of numerous genera and species of plants was conducted thanks to their work and engagement, including the taxonomic studies of representatives of large and small mammals, birds, insects, recent gastropods and bivalves.

The first post-war permanent exhibition was opened on 1 May 1946. Petar Stevanović, Zarija Bešić, Pavle Černjavski, Boris Petrov and their associates participated in its preparation (Figure 24). In 1952, this exhibition was replaced by the thematic exhibition Protection of Nature, organised in cooperation with the Institute for the Protection of Nature and Natural Rarities of the Republic of Serbia and the Museum of Forestry and Hunting. The last permanent exhibition titled Inanimate and Living Nature was opened in 1964, in the basement of the Museum's courtyard building (Kneginje Zorke Str. 57), which was adapted for that purpose. It was permanently closed in 1986, to prevent the deterioration of the exhibits caused by moisture. The Museum had no permanent exhibitions since then, and smaller thematic exhibitions are now organised at the Museum Gallery in Kalemegdan.

In the first post-war decade, the exhibition space was expanded to include new, external pavilions that were a part of the elementary school "Radoje Domanović" (1956), where the first Yugoslav school natural history museum was founded, and in the Pioneer City in Košutnjak (1958), where the first permanent exhibition for pioneers $^{5}$ was opened in cooperation with the Natural History Museum and the Museum of Forestry and Hunting.

${ }^{5}$ Children of age seven and older, also known as Tito's Pioneers, during the Communist period of Yugoslavia. 


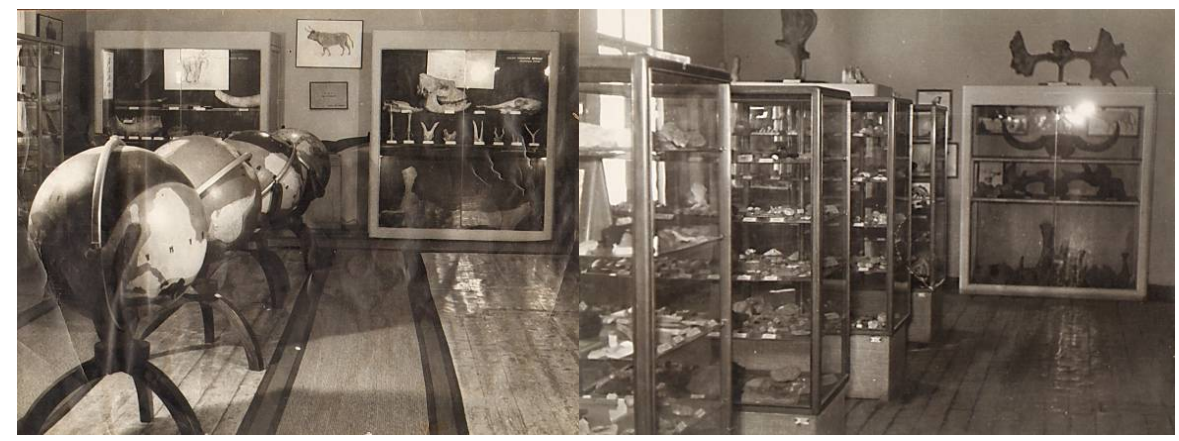

Fig. 24. - Detail from the first post-war exhibition of the Museum (photo library of the Museum, Jovanović 2010).

Exhibitions Minerals of the Trepča Mine (1950/1951), Nature of the Area Surrounding Belgrade (1963), Life and Work of Josif Pančić (1963), Minerals and Ores of Serbia (1965), Birds of Our Land (1968)), Evolution of the Organic World According to Geological Periods (1969), Living World in the Aquatic Environment (1971), Fragments from the Nature (1972) and Hunting Trophies (1973) were especially important, both in terms of topics and the number of visitors.

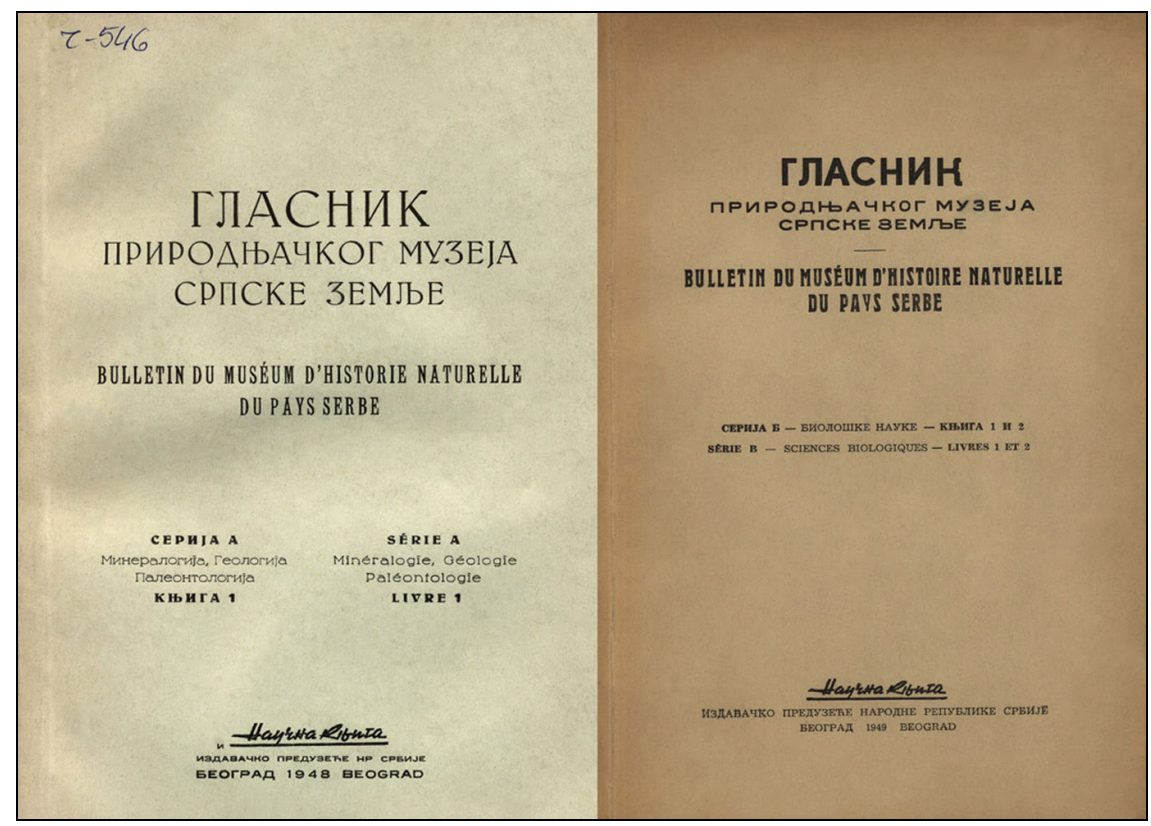

Fig. 25. - First editions of the scientific journal Bulletin of the National History Museum of the Serbian Land, series A and B.

The first issue of the "Bulletin of the National History Museum of the Serbian Land" (Glasnik Prirodnjačkog muzeja srspke zemlje) from series A 
(mineralogy, geology, paleontology) was printed in 1948, while that from series B (biological sciences) was printed in 1949 (Figure 25). The name

was changed in 1958 to "Bulletin of the Natural History Museum in Belgrade" (Glasnik Prirodnjačkog muzeja u Beogradu) and the journal was published regularly under this name until 1998, when its publication was terminated due to the lack of financial resources. In the 50 years of its running, the journal presented 1,091 articles (series A: 455; series B: 636), mostly in Serbo-Croatian, with summaries provided in English, German, French and Russian (Mučalica-Milanović 2003).

The appeal of Petar Pavlović from 5 November 1924, submitted to the Ministry of Education and requesting a ban on unauthorised excavation in the Zlot Cave (eastern Serbia) was in fact the first proposal for the protection of natural resources in Serbia (ANHM 16/1924). In 1945, Museum experts launched initiatives for the protection of the "green belt around Belgrade", the nature of Kopaonik and the Obedska Bara forest complex (ANHM 16/1945). In 1948, at the suggestion of the Museum, the Ministry of Forestry of the Republic of Serbia passed a decision on the protection of 180 hectares of beech forest on Ostrozub, near Crna Trava, with the aim of preserving the local population of the cherry laurel plant. This act marked the beginning of the era of modern nature protection in Serbia. The Institute for the Protection and Scientific Study of Natural Rarities of the Republic of Serbia was establishedth at same year.

The first explorations at the Gluvi Potok site in Prebreza (Toplica valley, southern Serbia, Figures 26 \& 27) began in 1958, causing the discovery of accumulations/lumacheles of fossilised bones of large mammals, antelopes, gazelles, giraffes, hyenas, wild boars and elephants. In addition to the species that were recorded in Europe for the first time, later studies also identified representatives of two species that were new to science: hyena (Precrocuta miocenica Pavlović \& Thenius, 1965) and a predecessor of gazelle (Hipsodontus serbicus Pavlović, 1969). The site itself was declared one of the most important Neogene fossiliferous sites in the Balkans.

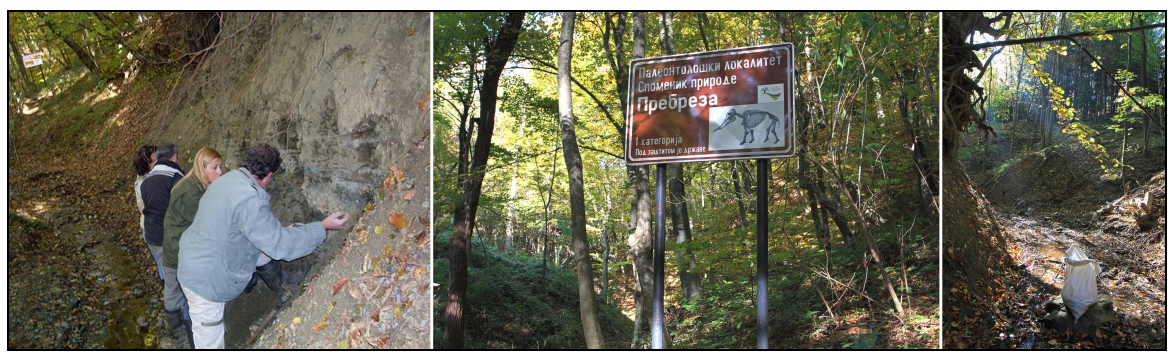

Fig. 26. - Gluvi potok site (photo: Z. Marković \& A. Maran Stevanović). 


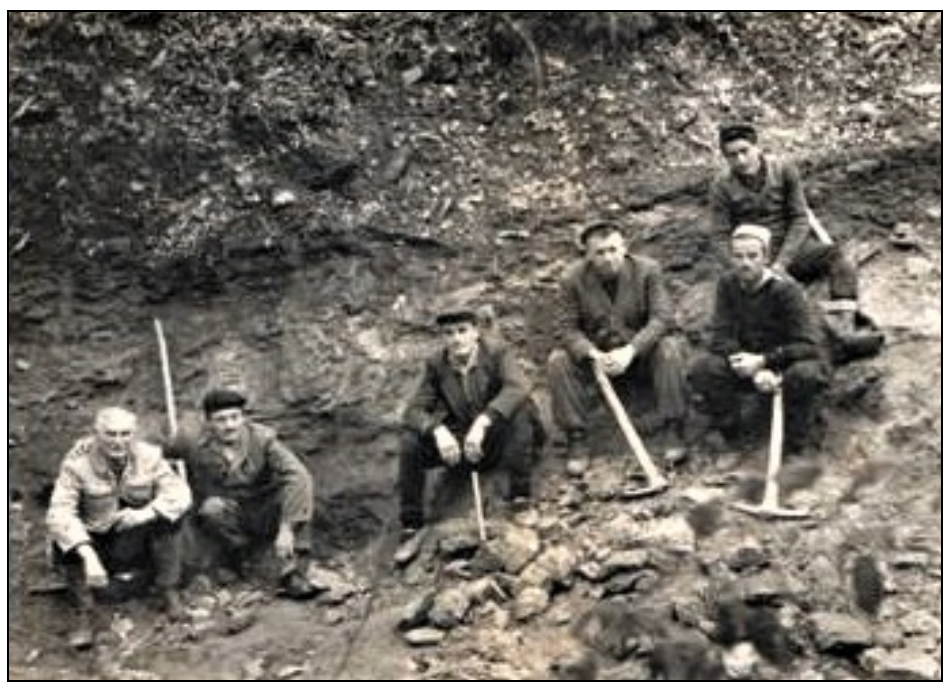

Fig. 27. - The first excavation at Gluvi potok site in 1958.

Exploration and protection of natural and cultural heritage in the area of Djerdap took place in the period 1965-1970. The immediate reason for this was the construction of a dam on the Danube and the creation of an accumulation lake upstream from Kladovo. In order to study, collect and document as much data and materials as possible about natural phenomena in the part of the Djerdap gorge that was to be submerged after the construction of the dam, curators, conservators and preparators of the Natural History Museum conducted detailed geological and biological

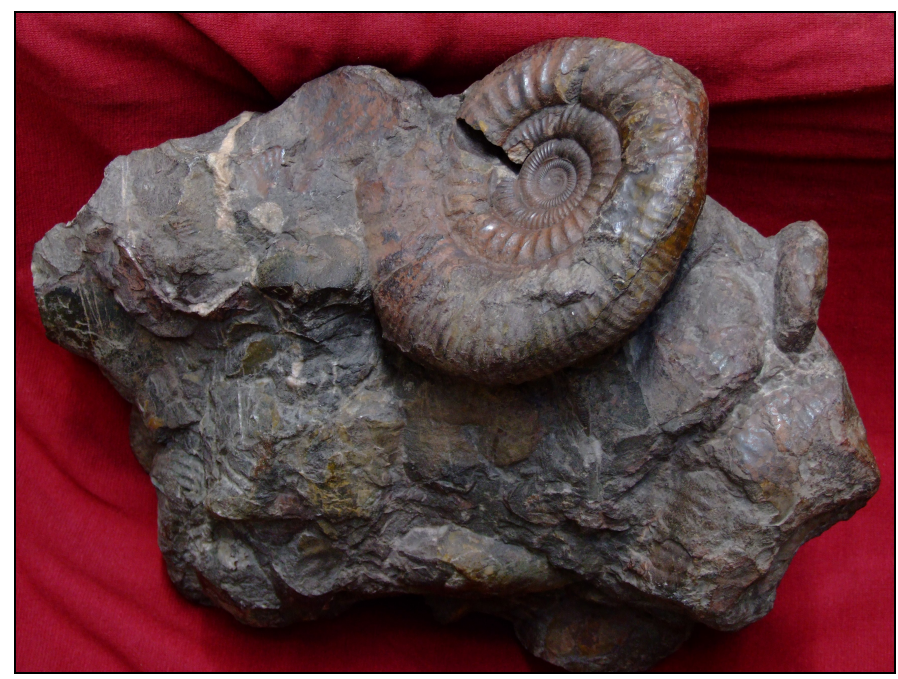

Fig. 28. - Fossilized ammonites, Greben locality, Djerdap gorge. 
investigations, together with experts from the Serbian Institute for Protection of Nature and other institutions. That is when the localities of Greben, Radovanjski Potok, the canyon of Boljetinska Reka river and Pesača were explored and marine sediments from the Jurassic and Lower Cretaceous periods were discovered, abundant in fossilised remains of ammonites (Figure 28), belemnites, brachiopods, gastropods and bivalves. They are now kept in the Museum's Collection of Mesosoic invertebrates. Botanical research included the collection of herbarium material and creation of the list of flora representatives in the coastal and hilly zone of Djerdap, with proposals for appropriate conservation regimes for species that were recognised as natural rarities. Data on mammological, ornithological, herpetological, malacological and entomological material were collected by doing fauna-related research.

In 1973, the Museum of Forestry and Hunting was annexed to the Natural History Museum by decision of the Assembly of the City of Belgrade. The Museum of Hunting and Forestry was founded in Milošev Konak (Topčider) in 1932 (Figure 29), and the first collections were obtained from the Ministry of Forests and Mines and forest ranger schools from around Serbia (Gordić 1993). In 1953, due to the planned relocation of a part of the Historical Museum of Serbia to Milošev Konak, the collections of the Museum of Forestry and Hunting were temporarily housed in the premises of the Faculty of Forestry. They were transferred to the Guard Building on the Great Ravelin of the Belgrade Fortress in 1957.

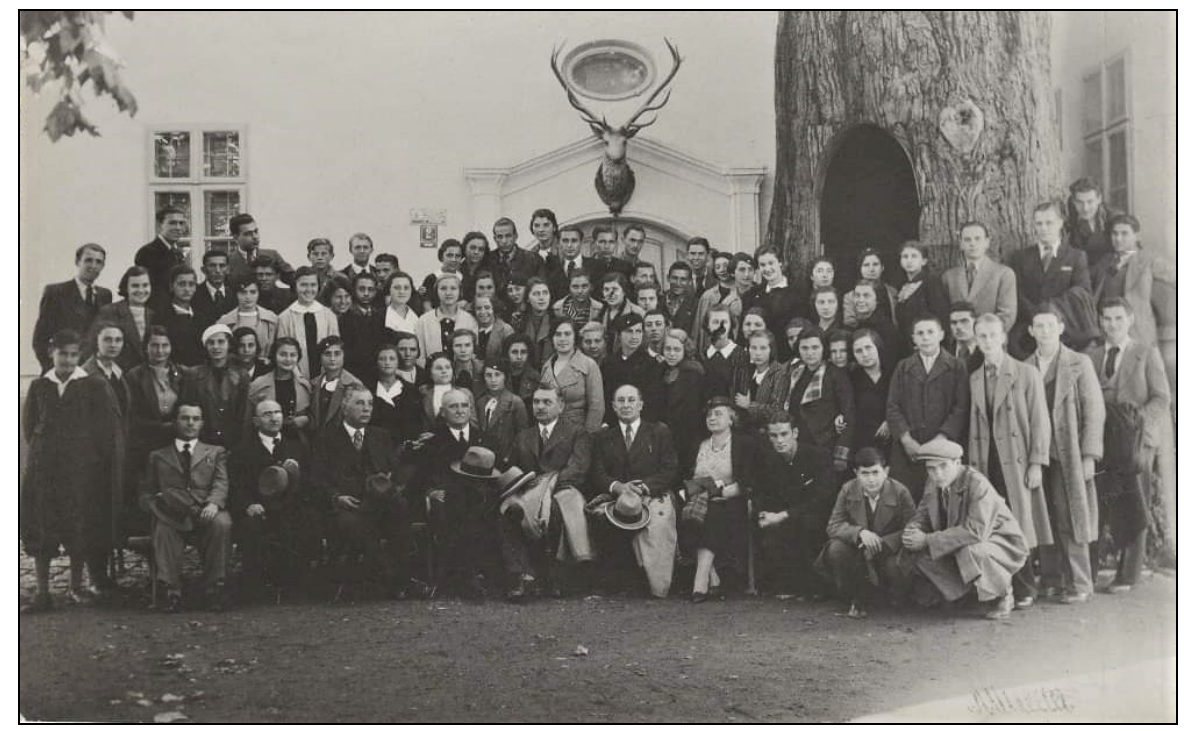

Fig. 29. - The Museum of Hunting and Forestry in Milošev Konak, Topčider, recorded in 1932 (archive of D. Gajić, Facebook forum "Once upon a time there was one Belgrade"). 
The Guard Building on the Belgrade Fortress' Great Ravelin is located between the Outer Stambol Gate and the Gate of Karadjordje. It is assumed that it was built in the third or fourth decade of the $19^{\text {th }}$ century because it appears for the first time, as a constructed object, on the "Turkish Blueprint” from 1863 (Gordić 1993; Popović \& Božić 1994). It served as a watchtower or a place for guards and was designed to provide and control the fortification and communication direction of the entrance to the Upper Town fortress. The then appearance of the building was immortalised by the famous photographer Anastas Jovanović on 19 April 1867, when the keys to Belgrade were handed over to Prince Mihailo Obrenović (Figure 30). Over time, it also served other purposes, first as a garrison infirmary and then a residence for military commanders. As regards the historical development of Belgrade and the Belgrade Fortress, the Guard Building represents important material evidence as one of the few well preserved profane buildings from the period of Classicism (Božović 2017).

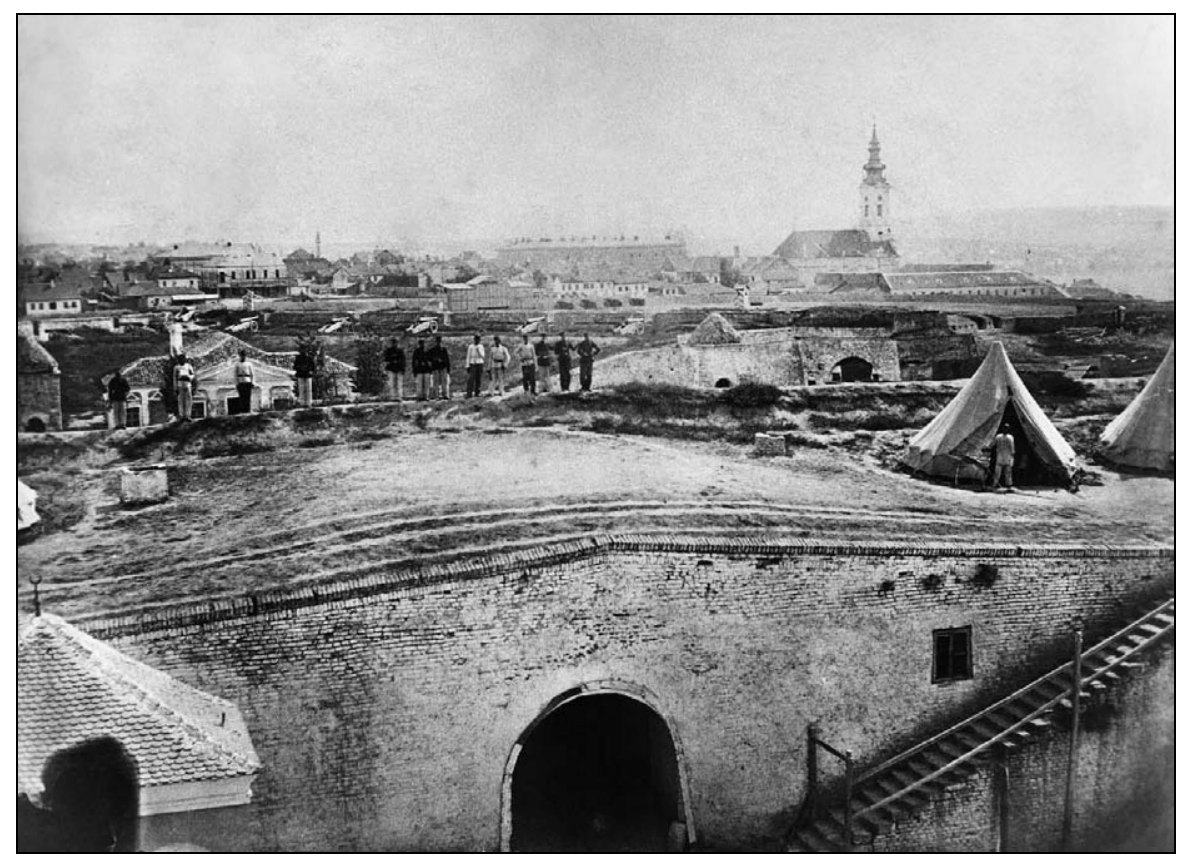

Fig. 30. - The Stambol Gate with the Great Ravelin and the Guard Building in the background; photograph by Anastas Jovanović, made during the handover of the keys of Belgrade to Prince Mihailo Obrenović, 19 April 1867 (Popović 2006).

Despite its specific appearance, the building languished on the margins of interest for a long time, and its origin and meaning were obscured by various historically unfounded stories (Popović \& Božić 1994). According to some sources, it used to serve as the residence of Haji Mustafa Pasha, the vizier of the Belgrade pashaluq, known by the nickname Mother to Serbs 
(Srpska majka) because of his benevolent attitude towards the local population. Legend says that freemasons used to gather in his home and it was consequently believed that the first Masonic lodge in Belgrade, whose founder and great master was a Turk, was formed right there, under the name "Ali Koč" (Stefanović 2019). However, older people who used to take walks in Kalemegdan remember this building as the Museum of Forestry and Hunting. They also remember the elephant's foot that, for many years, used to "welcome" visitors at the entrance.

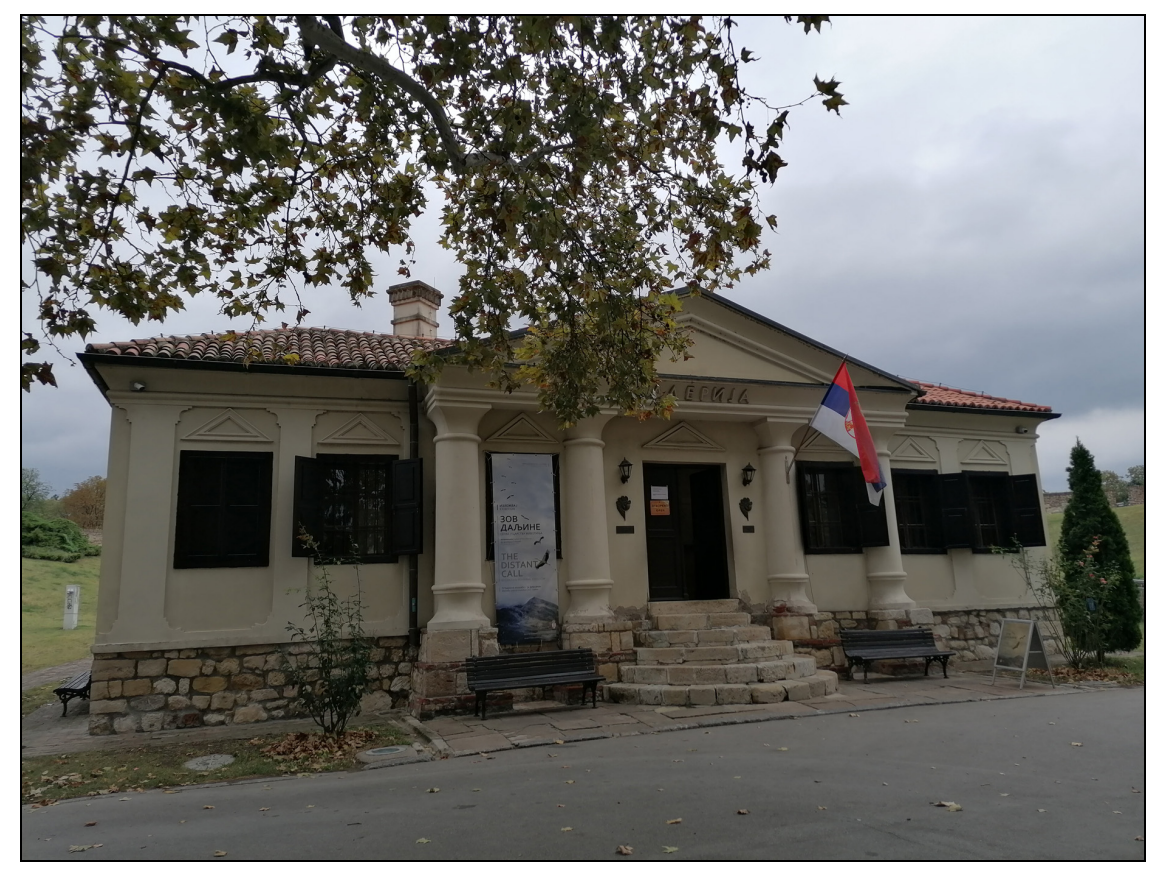

Fig. 31. - Gallery of the Natural History Museum, one of the symbols of Kalemegdan (photo: A. Maran Stevanović).

\section{CONCLUDING REMARK}

In the year of great jubilee, an old dream of generations of Museum experts and its admirers has still not come true - to provide a worthy place for dwelling valuable natural collections and their presentation to the public. That is why the Call for the Museum of the Serbian Land reminds and resonates even today: “... every state and every enlightened people has raise real temples in which they live and serve their Nature and its Creator, in which the people are shown all the natural treasures of his country, and the youth learn to know and love their homeland entirely ... only in Serbia that is not the case". 


\section{REFERENCES}

Anonimus (1895): Prirodni dom ili Jestastvenički Muzej u Beogradu. - Srpska Zastava 29: decembar 1895.

Anonimus (1896): Jestastvenički Muzej Srpske Zemlje i neke okolnosti. - Srpska Zastava 26: novembar 1896.

Anonimus (1898): Etnološki Muzej i Muzej Srspke Zemlje. - Prosvetni zapisi, Prosvetni glasnik, Službeni list Ministarstva prosvete i crkvenih poslova Kraljevine Srbije 19: 613/73.

Anonimus (1939): Građenje Etnografskog muzeja. - Dnevni list „Vreme“, 2. avgust 1939: 5.

Anonimus (1956): Beogradski muzeji: Etnografski muzej. - Godišnjak Muzeja grada Beograda 1: 316-321.

Božović, A. (2017): Zgrada straže na Velikom ravelinu. - Godišnjak Prirodnjačkog muzeja u Beogradu 26-29.

Cvetković, B. (2011): Između privatnog i javnog: Stevča Mihailović. - Zbornik Matice srpske za likovne umetnosti 39: 145-165.

Dinić, A. (2012): The most important researchers of forests in Serbia. - Bulletin of the Natural History Museum in Belgrade 5: 103-122.

Drobnjaković, M. B. (1938): Muzej Srpske Zemlje u 1937. godini. - Godišnjak Srpske Kraljevske Akademije 47: 267-274.

Gojković, B. (1954): Prirodnjački muzej srpske zemlje. - Godišnjak muzeja grada Beograda 1: 322.

Gordić, M. (1993): Muzej šumarstva i lova/Loža slobodnih zidara/Mali Kalemegdan. Glavni projekat sanacije i rekonstrukcije Zgrade straže na Velikom ravelinu - izvedeno stanje, Istorijat i valorizacija. - Zavod za zaštitu spomenika kulture grada Beograda, 1-3.

Inđić, T. (2009): Slučaj Prirodnjačkog muzeja ili o nacionalnom nehatu: kirajdžije iz Džehanine kuće. - Društvo „Sveti Sava“, Bratstvo 13: 101-119.

Jovanović, M. (2010): Izložbe Prirodnjačkog muzeja 1903-2004. Arhiva Prirodnjačkog muzeja: 1-76. (Habilitacioni rad za zvanje višeg kustosa) (rukopis).

Jovanović Simić, J. (2006): Muzej Srpske medicine Srpskog lekarskog društva. Acta medico-historica Adriatica 4(2): 323-330.

Jović, V. (2008): The development of Geology in Serbia. In: Ninković, S., Grujić, P. V. (eds.) Proceedings of the meeting "Studying nature through centuries", Publications of the Astronomical Observatory of Belgrade 85: 113-127.

Macdonald, Sharon J. (2003): Museums, national, postnational and transcultural identities. - Museum and society 1(1): 1-16.

Maran Stevanović, A. (2014): Od stene do stene-portret naučnika: Petar Stevanović 1914-1999-2014. - Prirodnjački muzej u Beogradu, Službeni glasnik, Beograd: $1-61$.

Matvejev, S. 2006: Moja biografija, Pisana u nastavcima između ratova. - Srpsko biološko društvo „Stevan Jakovljević“ Kragujevac. Grafički atelje Skver, 282 str. 
Mučalica-Milanović, M. (2003): Biblioteka Prirodnjačkog muzeja - 100 godina posle (CD izdat povodom stogodišnjice biblioteke Prirodnjačkog muzeja).

Pavlović, P. (1905): Izveštaj o radu Muzeja Srpske Zemlje za 1904. god. Godišnjak Srpske Kraljevske Akademije, 18, 24 str.

Pavlović, P. (1906): Izveštaj o radu Muzeja Srpske Zemlje za 1905. god. Godišnjak Srpske Kraljevske Akademije, 19, 20 str.

Pavlović, P. (1907): Izveštaj o stanju Muzeja Srpske Zemlje za 1906. god. Godišnjak Srpske Kraljevske Akademije 19, 22 str.

Pavlović, P. (1908): Muzej Srpske Zemlje u 1907. god. - Godišnjak Srpske Kraljevske Akademije 21, 20 str.

Pavlović, P. (1911): Muzej Srpske Zemlje u 1910. god. - Godišnjak Srpske Kraljevske Akademij 24, 17 str.

Pavlović, P. (1912): Muzej Srpske Zemlje u 1911. god. - Godišnjak Srpske Kraljevske Akademije 25, 21 str.

Pavlović, P. (1920): Izveštaji Narodnog Muzeja, Muzeja Srpske Zemlje i Etnografskog muzeja u 1914, 1915, 1916, 1917, 1918 i 1919. god. - Godišnjak Srpske Kraljevske Akademije 28: 208-229.

Pavlović, P. (1922): Muzej Srpske Zemlje u 1921. g. - Godišnjak Srpske Kraljevske Akademije 30, 23 str.

Popović, M. 2006: Beogradska tvrđava/The Fortress of Belgrade. Javno preduzeće „Beogradska tvrđava“ \& Arheološki institut i Zavod za zaštitu spomenika kulture grada Beograda, Birograf, str. 282, 291, sl. 175, 184.

Popović, M., Božović, R. (1994): Glavni projekat sanacije i rekonstrukcije Zgrade straže na Velikom ravelinu - izvedeno stanje. - Zavod za zaštitu spomenika kulture grada Beograda, 1-5.

Simić-Milovanović, Z. (1954): Beograd kroz muzejski materijal. - Godišnjak Muzeja grada Beograda 1: 9-44.

Stanojlović, N. (2003): Testament Stefana-Stevče Mihailovića. Koreni. - Istorijski arhiv Jagodina 1: 155-168.

Stefanović, N. N. (2019): Beograd kroz ključaonice 100 kuća. - Laguna, Beograd, 624 str.

Stevanović, P. (1960): Dobrivoje P. Stojadinović, preparator Muzeja (1882-1959). - Glasnik Prirodnjačkog muzeja u Beogradu A 13: 3-6.

Stojićević, D. (1929): Muzej Srpske Zemlje u 1929 godini. - Godišnjak Srpske Kraljevske Akademije 38, 6 str.

Stojićević, D. (1937): Muzej Srpske Zemlje u 1936 godini. - Godišnjak Srpske Kraljevske Akademije 46, 4 str.

Vasić, O., Niketić, M. (2014): Putovanje. Josif Pančić (1814-1888). - Prirodnjački muzej u Beogradu, JP „Službeni glasnik“, Beograd.

Vicić, D., Vicić S. (2008): Pozdrav iz Beograda 1895-1941. - Atelje Vicić 2: 1-337.

Žujović, J. (1889): Le docteur Josif Pančić. - Geološki anali Balkanskoga poluostrva 1(2): $122-132$. 
Žujović, J. (1890): Velikoškolski kabinet za mineralogiju, geologiju i paleontologiju. Izveštaj za god.1880-1888. - Geološki anali Balkanskoga poluostrva 1(2): $84-114$.

Novine Serbske (1852): br. 97/1852.

Archives of the Natural History Museum (ANHM) / Arhiva Prirodnjačkog muzeja u Beogradu (APM)

APM (1895): Dopis Ministra prosvete i crkvenih poslova Predsedniku Kraljevske Akademije br. 24285/19. decembar 1895. godine.

APM 5/1897-1899: Dokumentacija o finansijsko-materijalnom poslovanju prilozi za podizanje Muzeja.

APM 1/1898: Dopis Ministra prosvete i crkvenih poslova čuvaru Narodnog muzeja br. 18202/23. oktobar 1898. godine.

APM 3/1919: Spisak knjiga u Muzeju Srpske Zemlje koje su upropastile austrijske okupacione vlasti br. 26/16. maj 1919. godine.

APM 4/1919: Dopis Petra Pavlovića Ministarstvu prosvete i crkvenih poslova o stanju biblioteke Muzeja.

APM 16/1924: Dopis Petra Pavlovića Ministarstva prosvete za zabranu neovlašćenih iskopavanja na prostoru Zlotske pećine br. 214/5. novembar 1924. godine.

APM 1/1938: Rešenje o raspisivanju konkursa za izradu idejnih skica za novu zgradu Etnografskog muzeja br. 13878/38/3. maj 1938. godine.

APM 1/1938: Rešenje o privremenom smeštaju Etnografskom muzeja i Muzeja srpske zemlje u prostorije zgrade Prve ženske gimnazije u Beogradu br. 15800/20. maj 1938.

APM 1/1938: Primopredaja zgrade Prve ženske gimnazije br. 4516/68, 8. jul 1938. godine.

APM 1/1941: Plan pripremnih radova za organizaciju Botaničke bašte na Avali, Pavle Černjavski, br. 72/20. februar 1941. godine.

APM 1/1941: Situaciona skica za podizanje Muzeja srpske zemlje u Beogradu (1:25000).

APM 1/1942: Spisak službenika Muzeja srpske zemlje koji su penzionisani, napustili našu teritoriju ili se nalaze u zarobljeništvu, sastavljenom po naređenju br. 334/42 od 14. aprila 1942. godine.

APM 1/1942: Naređenja Predsedništva Ministarstva prosvete o radu u državnoj službi u ratni uslovima br. 8889/2. jun 1942. godine, br. 1433/8. jun 1942. godine.

APM 1/1942: Izveštaj o radu Muzeja srpske zemlje Ministarstvu prosvete br. 171/10. jun 1942. godine.

APM 1/1942: Rešenje Ministarstva prosvete o zakupu stana Dimitrija Miodragovića, lekara, Kneginje Zorke 66, br. 17895/15. oktobar 1942. godine.

APM 1/1942: Izjave Milića Stevanovića i Katice M. Ivkovića da se P. Stevanović i M. Ivković nalaze u zarobljeništvu br. 344/24. decembar 1942. godine.

APM 16/1942: Motivacija za donošenje Uredbe o zaštiti prirode, o izradi Pravilnika rada Saveta za zaštitu prirode, Pravilnika i uputstva za prikupljanje 
prirodnih objekata u školama kao jedne nastavne jedinice i Pravilnika i uputstva za prikupljanje i čuvanje muzejskih objekata, 10. septembar 1942. godine.

APM 1/1944: Odeljenju za Visoke škole i druge naučne ustanove - Izveštaj o radu Muzeja srpske zemlje za vreme od 6. aprila 1941. do 20. decembra 1944. godine br. 5/27. decembar 1944. godine.

APM 16/1945: Dopis Ministarstvu prosvete Demokratske Federativne Jugoslavije / Vrhovni institut za zaštitu i naučno proučavanje spomenika kulture i prirodnjačkih vrednosti i Ministarstvu šuma Demokratske Federativne Jugoslavije apel za zaštitu Obedske bare u okolini Kupinova, 14. avgust 1945. godine; Dopis Ministarstvu prosvete Demokratske Federativne Jugoslavije/Vrhovni institut za zaštitu i naučno proučavanje spomenika kulture i prirodnjačkih vrednosti za zaštitu i čuvanje državne šume „Kopaonik“ br. 242, 15. avgust 1945; Sugestije Botaničkog odeljenja Muzeja srpske zemlje Ministarstvu šuma Srbije za zaštitu i čuvanje ostataka „Zelenog pojasa oko Beograda“ br. 437, 30. oktobar 1945. godine.

\title{
ПРИРОДЊАЧКИ МУЗЕЈ: ПУТОВАњЕ КРОЗ ВРЕМЕ И ПРОСТОР
}

\author{
АЛЕКСАНДРА МАРАН СТЕВАНОВИЋ
}

Р Е 3 И М Е

Поводом обележавања великог јубилеја, 125 година од оснивања Природњачког музеја у Београду, осветљене су историјске околности, важни догађаји и личности као и значајна истраживања и активности спроведене током првих 80 година његовог постојања. Чињеница да овим приказом није обухваћен савремени период Музеја последица је жеље аутора да то временско раздобље буде сагледано и протумачено из визуре других истраживача, још увек активних сведока. За припрему је коришћена обимна архивска грађа и фототека Музеја, музејски извештаји о раду, документи из личне заоставштине Петра Павловића, првог управника Музеја, као и белешке и мемоари некадашњих музејских прегаоца, Петра Стевановића и Сергеја Матвејева.

Природњачки музеј у Београду припада групи најстаријих националних институција. „Заснован“ је 19. децембра 1895. године под именом Јестаственички музеј, по налогу тадашњег министра просвете и црквених послова Љубомира Ковачевића. Специјализован је за заштиту и излагање покретних природњачких културних добара, 
обједињујући у својој делатности културну, научну и образовну функцију. Током историје мењао је називе и територијалну надлежност, али је његова мисија остала иста: прикупљање, научно и стручно проучавање, заштита и популаризација националног природног наслеђа, јачање свести шире јавности о његовом значају и неопходности да буде сачувано за будуће генерације.

Оснивач и први управник Музеја био је Петар Павловић (18641938), професор јестаственице Друге београдске гимназије, академик, геолог, палеонтолог и малаколог. Његово животно дело је формирање Музеја и обезбеђење његовог трајања у првим, бурним и драматичним деценијама XX века.

Иницијални фонд Музеја настао је у периоду 1901-1903. година. По одобрењу Министра просвете и црквених послова, највећи број природњачких предмета пренет је из Јестаственичког кабинета, Геолошког завода и Хемијске лабораторије при Великој школи и Рударског одељења Министарства народне привреде. Састојао се од 21 колекције палеонтолошких, петролошких, минералошких, зоолошких и ботаничких примерака велике научне, културне и историјске вредности. Драгоцене природњачке предмете приложили су и многобројни дародавци и школе. Ипак, научни основ из кога ће се временом формирати разноврстан и богат фонд музејских предмета постављен је захваљујући преданом раду, истраживањима и сакупљању материјала ботаничара Јосифа Панчића и његових следбеника, Јована Жујовића, Петра Павловића и Живојина Јуришића.

Библиотека Музеја званично је основана 1903. године. Први велики прилог и уједно почетни фонд музејске библиотеке била је целокупна стручна библиотека Лазара Докића (1845-1893), лекара, зоолога, професора Велике школе, председника Владе и Министра просвете, коју је породица након његове смрти даровала Музеју.

Првобитни план за Музеј, од кога се из различитих разлога одустало, била је изградња заједничког здања у које би се сместиле три институције, Српска Краљевска Академија, Народна библиотека и Јестаственички музеј, на уступљеном плацу код Делијске чесме, данас Кнез Михаилова улица 35.

Привремено седиште мењао два пута. Први пут, 1901. године, Музеју српске земље и Етнографском одељењу Народног музеја додељена је задужбинска кућа Стефана Стевче Михаиловића (18041888), једног од најутицајнијих српских политичара XIX века и великог добротвора. И други пут, 1938. године, због планираног рушења Стевчине задужбине, Музеј је заједно са Етнографским одељењем пресељен у објекте Прве женске реалне гимназије на 
Врачару, на раскрсници улица Његошеве и Кнегиње Зорке. Исте године, задужбина Стевче Михаиловића је срушена, али идеја о изградњи новог здања за Природњачки музеј никад није реализована. После ослобођења, на задужбинском плацу подигнути су објекти друге намене и власништва, а Етнографском музеју обезбеђен је смештај у згради некадашње Београдске берзе на Студенском тргу.

У години јубилеја и даље није остварен давнашњи сан генерација стручњака Музеја и његових поклоника - да се обезбеди достојан дом за драгоцене природњачке збирке и њихово представљање јавности. Зато Поклич за Музеј Српске земље и данас одјекује и подсећа: „... свака држава и сваки просвећени народ подигао је земљи на којој живи праве храмове у којима се служи служба и њеној Природи и њеноме Творцу, у којима се народу приказује цело природно благо његове земље, а омладина учи да своју отаџбину потпуно позна и љуби... само у Србији још тога нема“. 